\title{
A Study on Improving the Coefficient of Performance by Comparing Balancing Well and Standing Column Well Heat Exchange Systems
}

\author{
Myungkwan Lim ${ }^{1}\left(\mathbb{D}\right.$, Kyoungbin $\operatorname{Lim}^{2}$ and Changhee Lee ${ }^{3, *}$ \\ 1 Department of Architecture Engineering, Songwon University, Gwangju 61756, Korea; limmk79@naver.com \\ 2 Department of Mechanical Engineering, Hanbat National University, Daejeon 34258, Korea; \\ kblim024@hanbat.ac.kr \\ 3 Department of Mechanical and Shipbuilding Convergence Engineering, Pukyong National University, \\ Busan 48547, Korea \\ * Correspondence: leemech@pknu.ac.kr
}

Received: 17 October 2020; Accepted: 7 December 2020; Published: 14 December 2020

\begin{abstract}
This study proposed a technology to improve the performance characteristics and coefficient of performance (COP) of a geothermal system by fundamentally preventing underground water discharge and maintaining a constant temperature of the underground heat exchanger composed of bleed discharge water that utilizes two balancing wells using cross-mixing methods. Using the standing column well (SCW) and cross-mixing balancing well underground heat exchanger, we compared and analyzed the effective thermal conductivity characteristics and COP characteristics during heating and cooling modes. Consequently, the cross-mixing balancing well underground heat exchanger exhibited more effective thermal conductivity than the SCW underground heat exchanger, with a high COP. Therefore, suggesting the performance was improved using groundwater flow rather than SCW. The comparison and analysis results of the effective heat map characteristics using the results of the SCW and balancing well system showed that the heating operation for the SCW underground heat exchanger had better thermal conductivity characteristics than the cooling operation. In addition, regarding a balancing well underground heat exchanger, the cooling operation exhibited superior thermal conductivity characteristics. Thus, the performance was considered to have improved due to the flow of activated groundwater in the ground and the rapid heat transfer without heat accumulation.
\end{abstract}

Keywords: standing column well (SCW); thermal response test; effective thermal conductivity; thermal conductivity; balancing well; coefficient of performance (COP)

\section{Introduction}

The ground source heat pump system has been growing more than $10 \%$ annually in more than 30 countries over the past decade owing to its significant advantages utilizing renewable energy and high efficiency [1]. In Korea, installing systems in the public sector that utilize renewable energy is required in accordance with the recently implemented alternative energy use law, and the introduction of geothermal heat pump systems that use geothermal power have been increasing rapidly. A geothermal heat pump system maintains a constant temperature throughout the year by using underground heat sources $\left(15-16^{\circ} \mathrm{C}\right)$, indicating a higher system efficiency than air heat pump systems that use outdoor heat sources, whose temperatures vary with the season. The geothermal heat pump system consists of a heat pump, load-side heat exchanger, and underground heat exchanger responsible for cooling and heating loads. For a heat pump, a system (NR GT 101, 102, 103) [2-4] and a standard (KS B ISO 13256-1, 2) [5,6] have been prepared to meet the high efficiency of the heat pump according to test 
conditions. Recently, studies have been conducted to adjust the efficiency of the heat pump under test conditions. However, ground heat exchangers are not easy to develop as ground conditions vary per site. Among them, standing column well (SCW) underground heat exchangers have more shape-related and construction problems than other underground heat exchangers as they are returned to the same well after excavating a borehole in the ground, after collecting underground water that exists inside the well and directly and indirectly exchanging heat with the geothermal heat pump. In addition, the SCW-type underground heat exchanger is designed with excessive heat exchange capacity using foreign cases without considering the domestic reality; hence, the design of the geothermal heat pump system cannot be accurate.

Geothermal heat pump systems have been introduced and used in Korea since the early 2000s, and the supply and installation capacity have also increased every year. The geothermal heat pump system consists of a heat pump, which is responsible for the heating and cooling loads of buildings, and an underground heat exchanger, which absorbs and rejects heat from the ground. Ground heat exchangers are used to maintain a constant ground temperature throughout the year, indicating higher heat exchange efficiencies than those of air heat source heat exchangers. Standard term and regulations have not been established for SCW-type underground heat exchangers introduced in Korea; thus, there is much confusion about the application of SCW-type underground heat exchangers to geothermal heat pump systems depending on regional characteristics (e.g., geology, groundwater volume, number of aquifer layers, and level of development), installation methods, and shape of heat exchangers. Kim et al. [7] established the shape of the heat exchanger through standardization of products, including the shape and construction of an SCW underground heat exchanger, while establishing a measurement method for the underground thermal conductivity of SCW underground heat exchangers to develop a standard for the design capacity of the heat exchanger.

The effects of circulation water temperature, borehole heat resistance, and underground heat conductivity on various design and operational variables of SCW underground heat exchangers have been studied, and among these, the bleed has been reported to have the greatest effect on the heat transfer enhancement of SCW underground heat exchangers [8]. Bleeding is a method of operation in which underground water is extracted from a geothermal well, enters the heat pump, changes heat, and then releases some underground water to the surface during the process of injecting it back into the same well. The bleed rate is the ratio of the amount of groundwater extracted from the geothermal well and the amount of groundwater released to the surface. Bleeding can also induce underground water that exists near the geothermal well from the underground into the well. The heat exchange capacity of SCW underground heat exchangers can be increased through bleeding in areas where underground water is abundant. Guidelines on support for renewable energy facilities of the Korea Energy Corporation allow bleeding rates of up to $20 \%$ for SCW underground heat-burning machines [9]. However, a high rate of bleed application can drain the surrounding groundwater to which geothermal heat pump system is applied, and can also cause failure due to idling of the heat pump owing to the low groundwater level accumulating below the pump. Currently, various underground heat exchangers using thermal response tests have been studied both in Korea and internationally [10-15], and the energy equilibrium using thermal response test data has also been studied $[8,16]$. From the result of an analysis [17], it was reported that the temperature change of the underground heat exchanger circulation water tended to decrease as the bleed rate increased, and the underground thermal conductivity increased from $0 \%$ to $179 \%$ at a $0 \%$ to $30 \%$ bleed rate, respectively. Meanwhile, when groundwater was introduced from the underside of the underground heat exchanger, the underground heat exchanger circulation water mixed with groundwater from the bottom after exchanging heat with the ground; thus, the temperature change of the underground heat exchanger circulation water tended to rise initially over time. However, as the bleed rate increased, the rise tended to decelerate and remained constant if the bleed rate exceeded approximately $10 \%$.

Jang et al. [18] established a numerical analysis model of the SCW system with a finite volume analysis program that enabled repair-heat linkage. In addition, an effective repair conductivity was 
applied to simulate turbulence flow into a stratified current to assess its applicability. The numerical analysis was performed on the long-term behavior over 14 days, whereas the operation step of the SCW system was repeated. During the analysis, simulation of the heating mode was performed, and a numerical analysis was performed for two cases, i.e., the absence and presence of the application of the effective repair conductivity. The numerical analysis indicated the efficiency of applying the effective repair conductivity.

Numerous studies have been conducted using SCW geothermal heat pumps. Lee et al. [19] and Yang et al. [20] conducted studies on flow control and bleed control to improve the performance of SCW geothermal heat pumps, and then analyzed the performance improvement of SCW according to the presence or absence of a heat accumulator. To apply an SCW geothermal heat pump to collective residential facilities, Lee et al. [21] first modelled an SCW system based on whether the heat accumulator system was installed, and then analyzed the results of energy performance on a typical daily, monthly, and annual basis; consequently, the energy-saving effect consumed in heating and hot water production of buildings by installing the heat accumulator was analyzed.

When refilling an SCW ground heat exchanger bleed water by artificial incubation in another adjacent SCW-type ground heat exchanger, a case study of the change in the thermal conductivity found that the ground heat conductivity value was approximately 3.2 times higher than that measured at the same bleed rate in a single hole [22-24] (i.e., 3.24 and $2.96 \mathrm{~W} / \mathrm{m} . \mathrm{K}$ ), when the heat conductivity was measured individually by applying a single hole bleed rate of $20 \%$ for the two adjacent SCW-type underground heat exchangers. However, the same bleed rate was applied to inject the discharged groundwater into the adjacent underground heat exchanger. The thermal conductivity value of $\mathrm{K}$ was calculated. It was estimated that the two SCW-type underground heat exchangers were connected to a reciprocal aquifer, one at approximately $90 \mathrm{~m}$ underground and the other at $280 \mathrm{~m}$ underground, resulting in the return of the bleed water of each heavy heat exchanger to the relative underground heat exchanger side. The re-injection of mutually bleed discharge water, within the allowed bleed rate according to the Renewable Energy Center Geothermal Facility Construction Guide, showed a fairly high thermal conductivity improvement trend. It was predicted that converting the re-injection method (balancing well) of these bleed effluents would be advantageous to improve the performance of geothermal facilities installed with the existing SCW-type ground heat exchanger to ensure the overall stability of the entire geothermal facility.

Garcia-Gil et al. [25-27] analyzed two real groundwater heat pump systems using actual exploitation datasets to estimate the thermal energy demand bias and, via extrapolation, to assess the nature of thermal interferences between the systems by numerical methods. The results highlighted real case evidences of the benefits of managed groundwater bodies using this nesting system, which significantly reduced the energy transferred to the aquifer by up to two orders of magnitude, consequently withdrawing most of the thermal imbalance in global terms with respect to the aquifer $[25,26]$. The exploitation regimes of 27 groundwater heat pump systems from an alluvial aquifer were first examined using descriptive statistics. Linear relationships between abstraction and injection temperatures of the systems were assessed by calculating the Pearson's correlation coefficient and were used as evidence of thermal interferences. Then, the time series of flow rate, operation temperature, and energy transfer were modelled via spectral analysis and sinusoidal regression methods, and a definition of the relative exploitation patterns was developed [27]. Meng et al. [28] considered a low-carbon technology to provide heating and cooling for buildings in an urban environment and focused on the short- and long-term evolution of groundwater temperature induced by high-density ground source heat pump (GSHP) installations in an urban residential area in Cologne, Germany. Muela-Maya et al. [29] proposed a procedure that allowed efficient numerical simulations to be performed at an urban scale. Specifically, they proposed a novel methodology to optimize the data treatment of highly transient real exploitation regimes by integrating energy transfer in the environment to reduce more than 90\% registered raw datasets. Finally, Li et al. [30] showed that the thermal performance of the GSHP system could be significantly affected by complex geological 
substructures (such as ground stratification and groundwater advection). In this study, a seepage box was installed inside a two-layered laboratory device to investigate the heat transfer processes of unsaturated, saturated, and infiltrated ground. These results showed that the temperature and carried heat load of the cooler groundwater increased during the heat injection experiment and further contributed to various temperature distributions of the ground at different locations.

In this study, the thermal performance and coefficient of performance (COP) characteristics are analyzed by controlling the ratio of the entire groundwater to be returned to the two well holes using two well. Here, through comparison with the research results according to the bleeding rate, practical strengths and weaknesses are presented, and a study is conducted on the heat load characteristics applied to the actual system. For example, the heating and cooling modes were compared and analyzed for the temperature characteristics of the groundwater inlet and outlet when using the SCW underground heat exchanger, balancing well underground heat exchanger, and COP characteristics. In general, the thermal conductivity of an underground heat exchanger was measured when designing a building load. In this study, the heating and cooling modes were applied to the crossover operation of the balancing well to measure the thermal conductivity.

\section{Experimental Methodology}

Figure 1 presents the comparison test between the cooling and heating operations of the existing open underground heat exchanger to evaluate the energy efficiency and coefficient of performance (COP) of the system suitable for the on-site testing using the test method of the water-to-water geothermal source heat pump unit. An automatic cross-operating control system is used to maintain the optimal supply of heat sources for the existing SCW and to balance the well underground heat exchangers. The balancing well cross-mixed heat exchange geothermal heat pump system consists of a geothermal source heat pump and an underground heat exchanger and includes a cross-operation controller among the mechanical piping, circulation pump, and system control system.

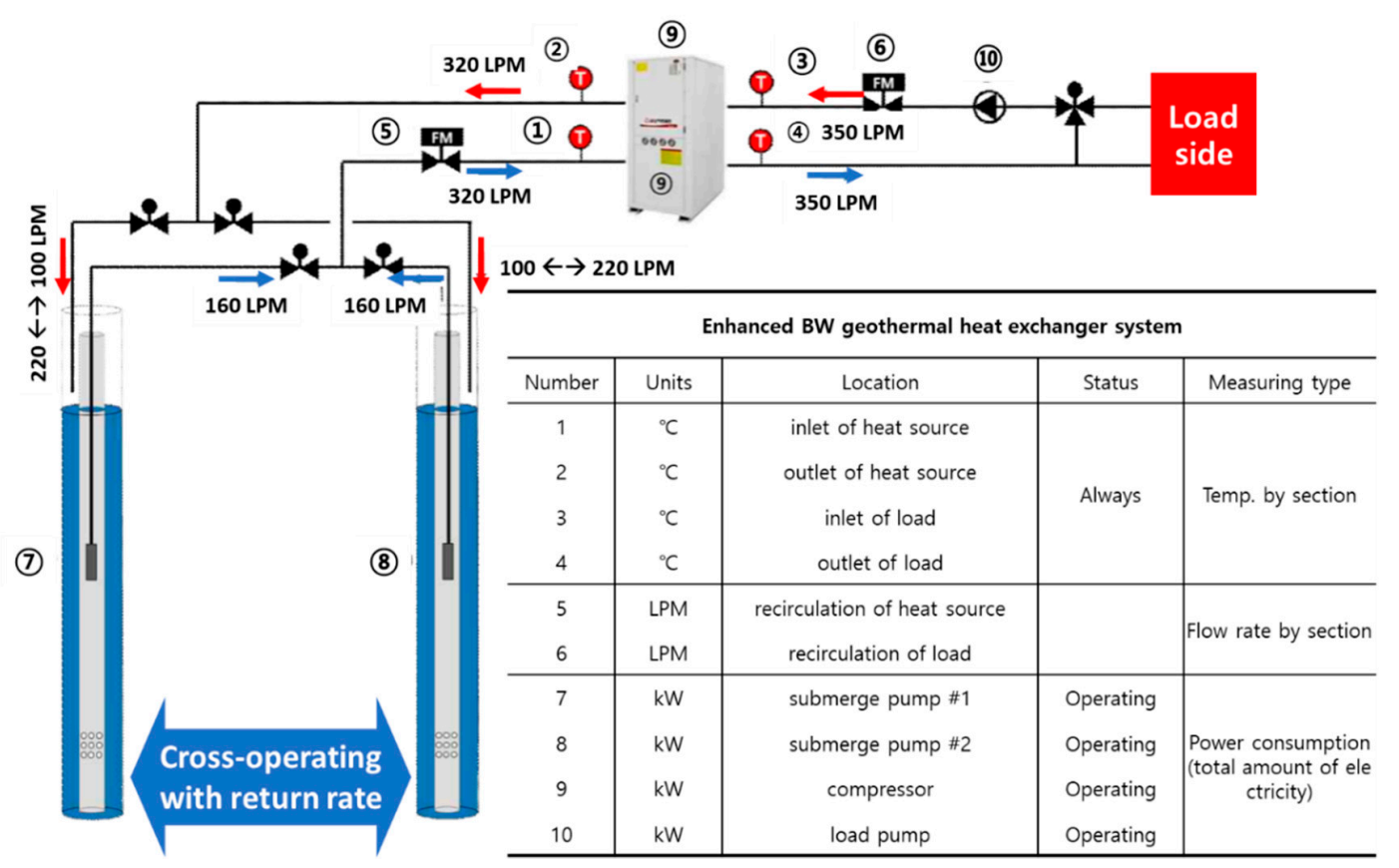

Figure 1. Schematic of the balancing well geothermal heat exchange system.

The test targets are one water-to-water geothermal source heat pump for 30RT-level cooling and heating and two underground heat exchangers with a typical SCW system installed with a diameter of $10 \mathrm{~mm}$ and at a depth of $300 \mathrm{~m}$. The SCW underground heat exchanger has a natural water level of $4.7 \mathrm{~m}$ and a maximum capacity of 350 tons/day. 
To verify that the experimental measurements were reasonable, as shown in Figure 1, a justifiable means of validation was required. The simplest expression of the heat balance equation is the following:

$$
\dot{q_{\text {in }}}=\dot{m} \cdot C_{p} \cdot\left(T_{\text {out }}-T_{\text {in }}\right)
$$

where $q_{\text {in }}(\mathrm{W})$ represents the measured heat input to the water heater elements and pumps; $\dot{m}$ (liter per minute, LPM) is the flow rate; $C_{p}$ denotes the specific heat of water; and $T_{\text {in }}$ and $T_{\text {out }}$ represent the temperatures measured with a thermostat.

After applying all the calibration equations to the measurement devices, the heat transfer rate predicted by the right-hand side of Equation (1) can be compared to the measured power input (left-hand side of Equation (1)). The numbers summarized in Table 1 are the average values over the length of each test. They were used to compare the instrumentation uncertainties and total heat input error.

Table 1. Heat balance check.

\begin{tabular}{ccccc}
\hline Location & Transducer Reading $(\mathbf{W})$ & Average $\mathbf{q}(\mathbf{W})$ & Difference $(\mathbf{W})$ & \% of Average Power \\
\hline A & 2506.6 & 2657.8 & 101.2 & 3.88 \\
B & 3207.2 & 3302.5 & 93.3 & 2.82 \\
\hline
\end{tabular}

The uncertainties in the temperature measurement were $\pm 0.01{ }^{\circ} \mathrm{C}$ for the probes and $\pm 0.04{ }^{\circ} \mathrm{C}$ for the signal conditioner of the digital displays with the analog signal. The total uncertainty for the temperature measurements is expressed in quadratic form, as shown in Equation (2):

$$
\Delta T=\sqrt{( \pm 0.01)_{\text {in }}^{2}+( \pm 0.04)_{\text {in }}^{2}}+\sqrt{( \pm 0.01)_{\text {out }}^{2}+( \pm 0.04)_{\text {out }}^{2}} \approx \pm 0.0825^{\circ} \mathrm{C}
$$

Considering that $\Delta T$ for each test is approximately $5{ }^{\circ} \mathrm{C}$, the uncertainty due to the temperature measurement becomes:

$$
\text { Error }=\frac{ \pm 0.0825^{\circ} \mathrm{C}}{5{ }^{\circ} \mathrm{C}} \times 100 \%=\approx \pm 1.65 \%
$$

Using the highest error for the flowmeter, taken from Table 2, of $\pm 2.03 \%$, the total uncertainty in the heat balance equation was computed as:

$$
\text { Total Error }=\sqrt{( \pm 0.0165)^{2}+( \pm 0.0203) 2} \approx 2.62 \%
$$

Table 2. Results from the flowmeter calibration.

\begin{tabular}{ccc}
\hline Actual Flow (LPM) & Calibration Flow (LPM) & Error (\%) \\
\hline 3.316 & 3.292 & 0.73 \\
15.87 & 16.032 & 1.01 \\
100.90 & 102.99 & 2.03 \\
350.62 & 355.41 & 1.35 \\
\hline
\end{tabular}

As shown in Figure 2, the balancing well cross-mixed heat exchange system is characterized by different operational methods in the two SCW-type geothermal heat exchangers with 100\% pumping from each geothermal heat exchanger, while the recovery quantity is different. In other words, the principle of generating the flow of groundwater in an underground aquifer was applied to generate a difference in the operational level of the two SCW geothermal heat exchangers. In this study, an experiment was performed using the cross-operating condition supply and return of $80 \%$ and $120 \%$, respectively, as shown in Figure 2a. If the circulation water supplied simultaneously from both of the ground heat exchangers was returned after the heat exchange, $120 \%$ of it was recovered by the ground 
heat exchanger (\#1 zone), and $80 \%$ of the remaining circulation was recovered by the other ground heat exchanger (\#2 zone) and the cross-operating mains, which were set to activate the aquifer by forming a difference in the groundwater level.

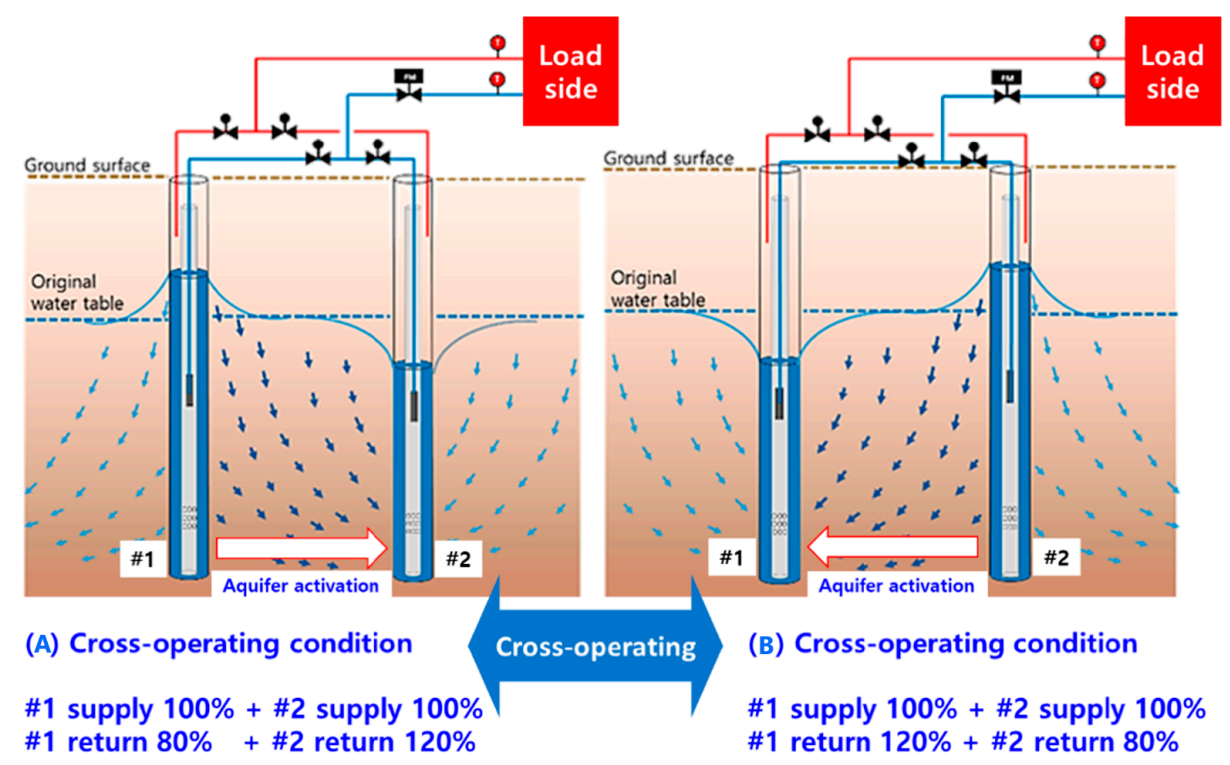

(a) Cross-mixing operating strategies for balancing well

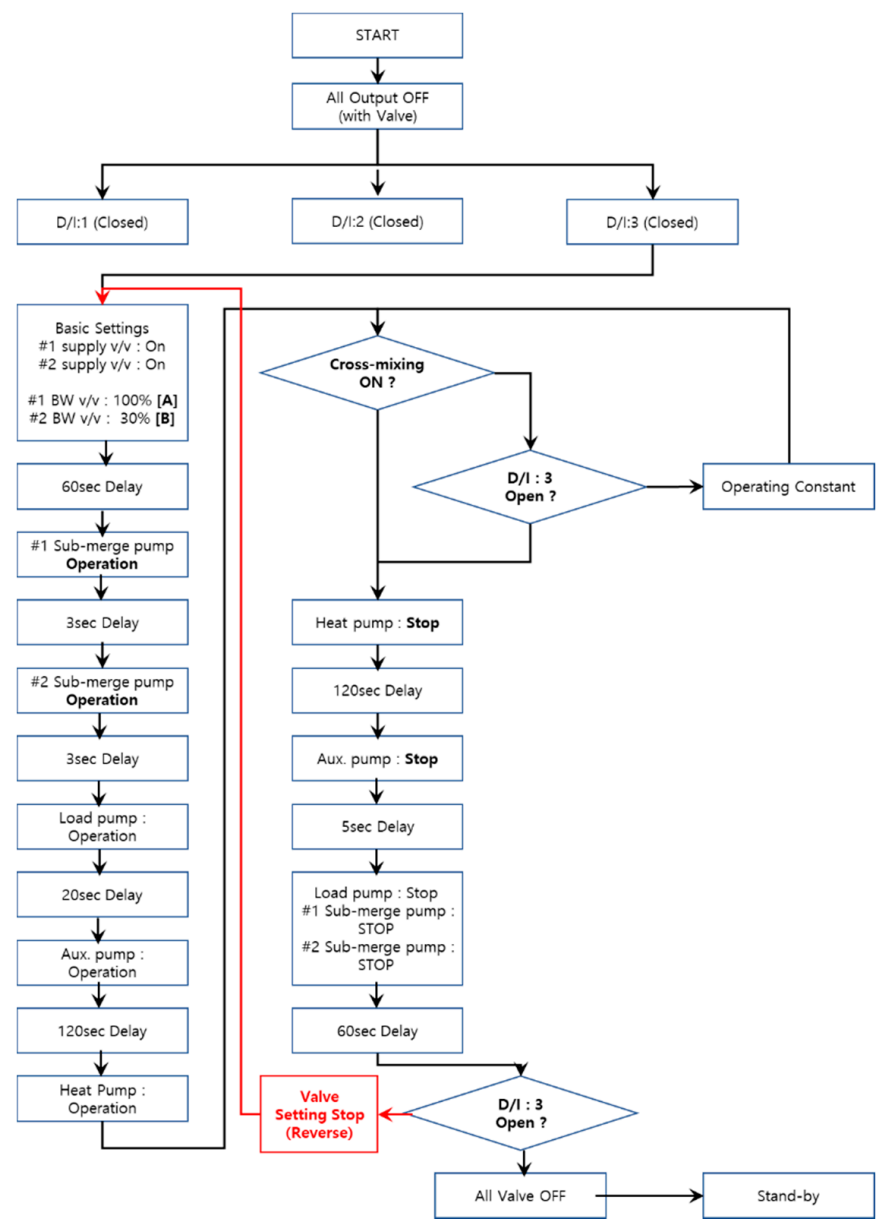

(b) Cross-mixing operating controller setting and control sequence for balancing well

Figure 2. Cross-mixing operation and condition for operating a balancing well geothermal heat exchanger. 
Figure $2 \mathrm{~b}$ demonstrates a flow chart depicting the balancing well cross control method. When the circulating water is supplied from the underground heat exchanger $(A)$ and the intermediate heat exchanger (B) performs heat exchange and is returned, $120 \%$ of the circulating water is returned to the underground heat exchanger (A-Zone), and the remaining is used in another underground heat exchanger (B-Zone). This system activates the aquifer by forming a groundwater level difference, and bleeding and recharging are controlled to alternately operate the system according to the set cross-operation cycle.

The system energy efficiency was calculated as the ratio of the resultant value of the produced heat obtained by applying the liquid enthalpy test method of the heat source and load sides to the COP of the system to compare it with the existing SCW geothermal system. In the liquid enthalpy method, the temperature, flow rate, and electricity consumption of the circulating water are recorded through the data logger at the entrance and exit of the heat exchanger on the heat source and the load side of the heat pump, respectively. The heat produced by the geothermal system is calculated using the following formulae:

$$
\begin{aligned}
& \text { Cooling mode : } \varnothing_{\text {tco }}=w_{f} c_{p f}\left(t_{f 4}-t_{f 3}\right)-\varnothing_{t}, \\
& \text { Heating mode : } \varnothing_{\text {tho }}=w_{f} c_{p f}\left(t_{f 3}-t_{f 4}\right)+\varnothing_{t},
\end{aligned}
$$

where $\varnothing_{\text {tco }}$ is the total cooling capacity of the heat pump $(\mathrm{W})$,

$\varnothing_{\text {tho }}$ is the total heating capacity of the heat pump (W),

$\mathrm{t}_{\mathrm{f} 3}$ is the heat pump inlet temperature $\left({ }^{\circ} \mathrm{C}\right)$ of circulating water on the source side,

$\mathrm{t}_{\mathrm{f} 4}$ is the heat pump outlet temperature $\left({ }^{\circ} \mathrm{C}\right)$ of circulating water on the source side,

$\mathrm{c}_{\mathrm{pf}}$ is the specific heat of heat source circulation water $\mathrm{J} /(\mathrm{kg} \cdot \mathrm{K}) \mathrm{]}$,

$\mathrm{w}_{\mathrm{f}}$ is the mss flow rate of circulating water on the heat source side $(\mathrm{kg} / \mathrm{s})$,

$\varnothing_{\mathrm{t}}$ is the total power consumption (W).

One of the most important aspects to consider in designing geothermal heat pump systems is the calculation of the length of the underground heat exchanger. To determine the number of geothermal heat exchangers required by the user, the amount of heat exchange present on the ground should be predicted by calculating the length of the appropriate underground heat exchanger for the design load. First, the method used to predict the underground thermal conductivity of SCW underground heat exchangers was used by applying the linear source method, which is used in vertically enclosed types.

The linear source theory is well established and has been applied to thermal performance tests since 1980 [31]. This approach has been extended to the comparative studies of energy losses in different heat exchanger arrays [32-34]. This line-source theory approach is applied to the thermal-response test data for the borehole heat exchanger (BHE) in the current research [35-42].

The effective thermal conductivity and thermal resistance can be obtained from the thermal-response test data using Equation (7) [43] as:

$$
\lambda_{\text {eff }}=\frac{Q}{4 \pi \mathrm{kH}^{\prime}}
$$

where $\lambda$ is the underground thermal conductivity of an SCW underground heat exchanger, $\mathrm{k}$ refers to the slope of the mean temperature variation curve of the circulation water over the logarithmic time, $\mathrm{Q}$ is the average amount of heat $(\mathrm{W})$, and $\mathrm{H}$ refers to the length of the geothermal well $(\mathrm{m})$. As expressed in Equation (7), the important factors that determine the amount of heat exchange in the underground heat exchanger are the underground temperature, length of the underground heat exchanger, and underground thermal conductivity. For SCW-type underground heat exchangers, the length of the heat exchanger is a crucial factor. In the case of vertical sealing, the depth of perforation from the trench depth is regarded as the length of the heat exchanger, and other sealed underground heat exchangers have similar tendencies. However, because SCW underground heat exchangers use 
underground water generated in a perforated well, it is difficult to confirm that the depth of perforation, as the length of the underground heat exchanger, is similar to that of an enclosed type, owing to various levels of groundwater depending on regional characteristics. The length of the underground heat exchanger, which was used for calculating the underground thermal conductivity, was defined as the length of the geothermal well, allowing more practical underground thermal conductivity to be induced. Hence, injecting heat from the underground heat exchanger into the underground heat exchanger is most preferred, which is used in the linear heat source method. This is because the thermal properties of the underground heat absorption and dissipation are the same under actual loads, when the actual amount of heat that is intended to be used is injected into the ground, and therefore the test can predict the thermal properties of the ground.

\section{Results and Investigations}

\subsection{Initial Ground-Water Temperature}

Figure $3 \mathrm{a}, \mathrm{b}$ shows the flow rates of the circulated water of the cross-mixed balancing well underground heat exchanger operating during the heating and cooling modes, average temperature and the temperature difference between the input and exit temperature of the ground, amount of heat injection to the power used by the system, power and instantaneous effective heat conductivity, and COP. The cross-mixed balancing well underground heat exchanger was operated by injecting it with 220 and 100 LPM of circulated water into the two underground holes. Owing to this operation, infinite energy of the ground is utilized through activation of the aquifer developed in the ground. In addition, this method is similar to the method that is based on the bleed rate, but the difference is identified with the utilization of underground water. In general, to control the bleed rate, only $80 \%$ of the water obtained from the water collector is injected as a recovery tool, and $20 \%$ of the underground water is utilized to show the characteristics of the underground heat exchanger. However, in this study, it was determined that by re-injection of the equally acquired circulating water between the two holes the water naturally moved from the a higher to a lower level, while using underground water more rapidly due to the inflow of underground water.

The flow rate injected into two holes (well) from the experimental conditions of the heating mode and cooling mode, shown in Figure 1, was maintained under the same conditions. The characteristics of the heating mode and the cooling mode can be observed through the temperature distribution. Clearly, the difference in the injection heat is determined by the temperature difference between the inlet and outlet temperatures. Finally, the linear source method was used to obtain the effective thermal conductivity. The cooling mode shows a higher efficiency than that of the heating mode, as observed from the results of the COP values in Figure 3. The effective thermal conductivity values obtained from Figure 1 in the heating and cooling modes were $11.3(\mathrm{~W} / \mathrm{m} \cdot \mathrm{K})$ and $16.2(\mathrm{~W} / \mathrm{m} \cdot \mathrm{K} 0$, respectively. From the results, the effective thermal conductivity value shows a higher value during the operation of the cooling mode than in the heating mode, and the experimental results are improved by approximately $70 \%$. This is assumed to be the result of improved circulation water returning to the ground through cross mixing, due to the rapid convection of fluids and underground water flow.

Figure $4 \mathrm{a}, \mathrm{b}$ shows the result of the flow rate of the water circulated to the SCW ground heat exchangers without any cross-mixing operating in heating and cooling modes, the difference in the average temperature of the ground and the temperature of the $\mathrm{I} / \mathrm{O}$, the amount of heat injection heat to the power used by the system, the power and ground of the equipment, and the instantaneous effective heat conductivity and COP. Unlike the cross-mixed balancing well ground heat exchanger, the SCW ground heat exchanger was operated by injecting 150 LPM of water into the two holes on the ground. An experiment was performed to obtain the difference between this operation method and the balancing well cross-mixing method. The trend in Figure 2 shows a trend similar to that shown in Figure 1. However, the results of the effective heat conductivity of the two systems were contradictory as compared with the cross-mixed balancing well underground heat exchanger of Figure 1 . This is 
because the cross-mixed balancing well method enables an active heat transfer owing to the changes in the recovery flow rate and activation of groundwater flow, while the SCW method does not actively intersect the underground water flow. The possible reason is that groundwater flow has not been activated because it maintains the same level.
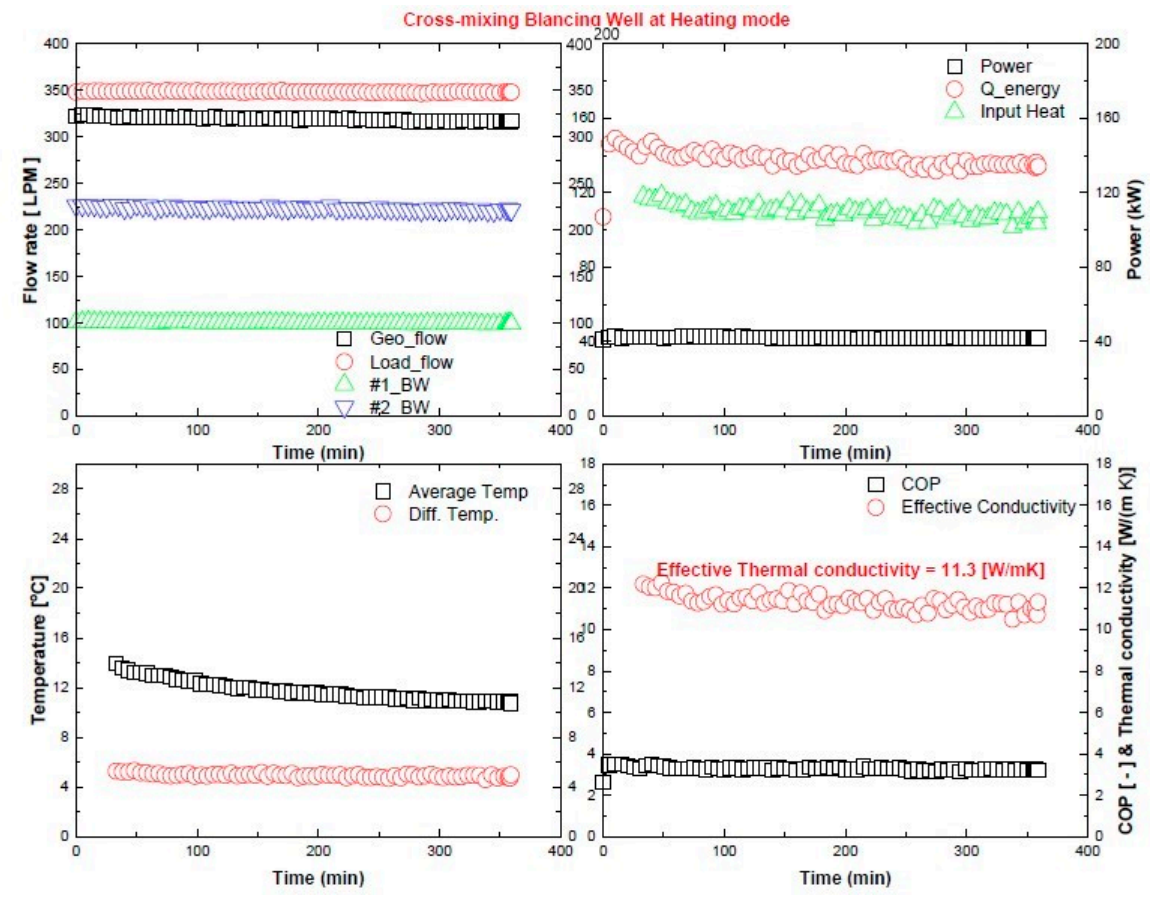

(a) Balancing well during heating operation
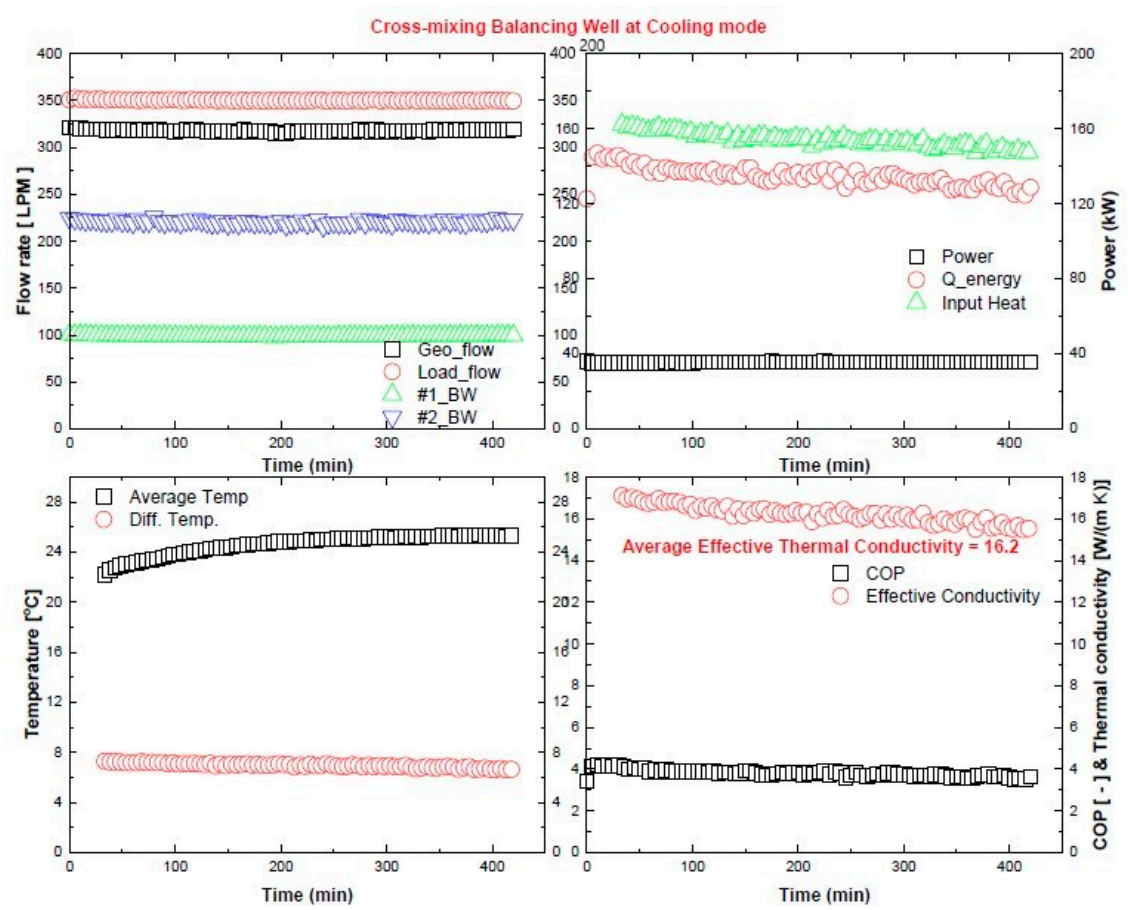

(b) Balancing well during the cooling operation

Figure 3. Flow rate of circulation water to the cross-mixed balancing well geothermal heat exchanger operating in heating and cooling modes (where \#1_BW and \#2_BW denote the discharge flow rate of the first and second submerge pumps shown in Figure 2, respectively). 

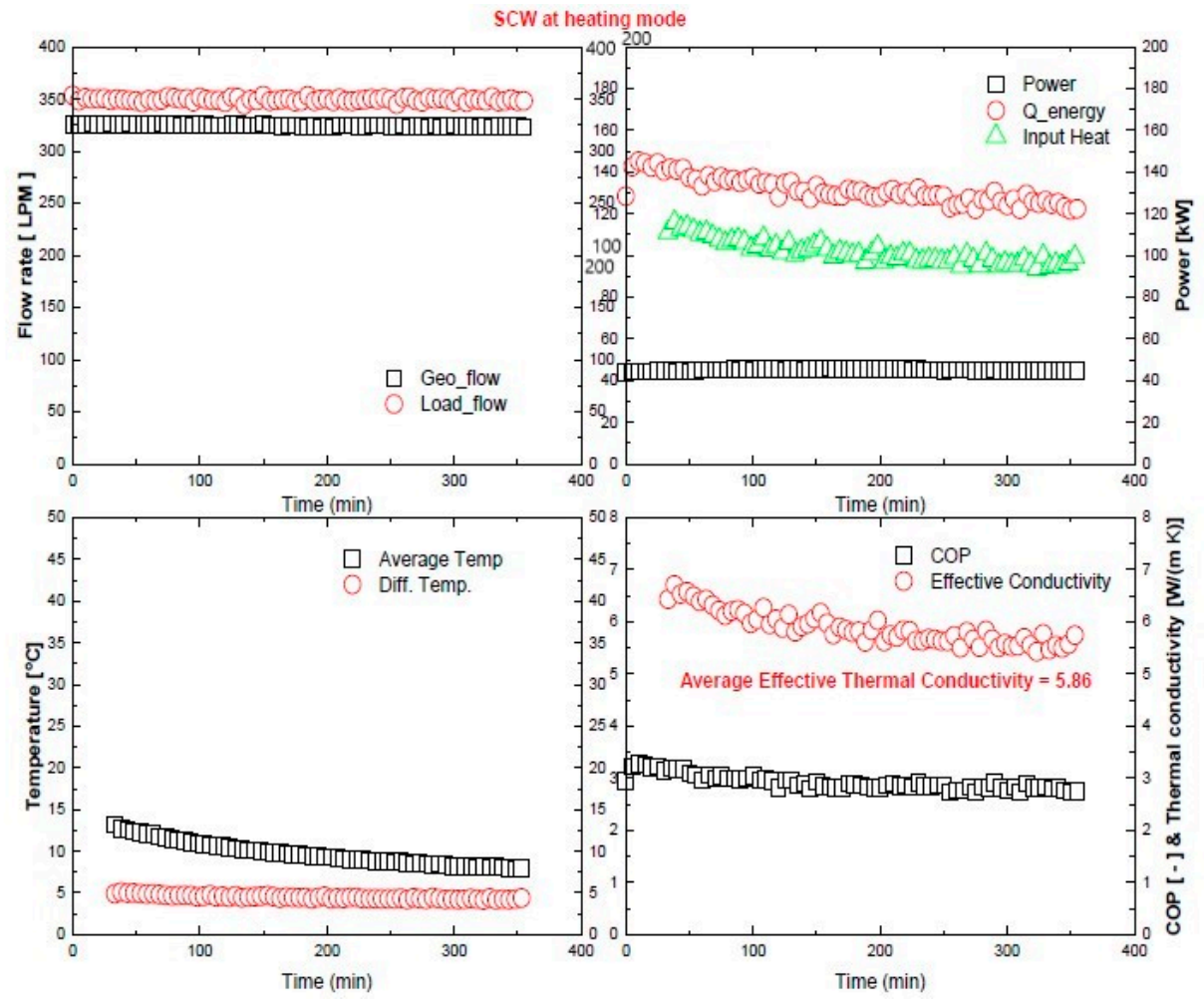

(a) SCW during heating operation
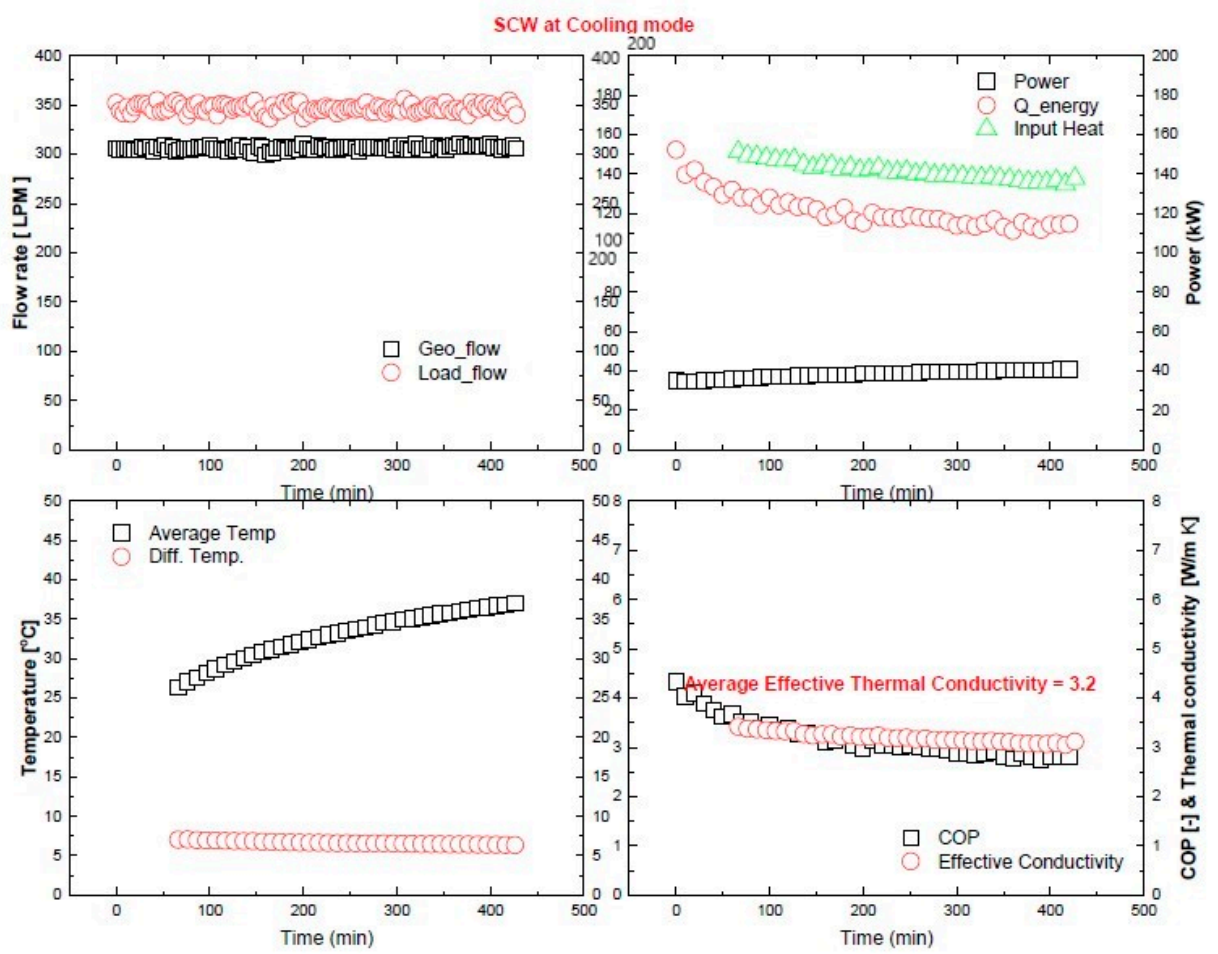

(b) SCW during cooling operation

Figure 4. Flow rate of circulation water to the standing column well (SCW) geothermal heat exchanger operating in heating and cooling modes. 
Figures 5 and 6 show the results obtained by evaluating the thermal performance of the soil for the SCW and balancing well geothermal heat exchangers. Figure 5 demonstrates the results of measuring the thermal performance of earth using the existing SCW method. The slope of the graph in Figure $5 \mathrm{~b}$ represents the $\mathrm{k}$ value of Equation (7) presented in the line-source method. Using Equation (7), the effective heat transfer of the SCW underground heat exchanger can be obtained. As shown in Table 3 , the effective heat transfer value is $3.075(\mathrm{~W} / \mathrm{m} \cdot \mathrm{K})$. Figure 6 presents the results of measuring the thermal performance using a cross-mixing balancing well underground heat exchanger method. As previously described, the thermal performance was measured using the same line-source method. As mentioned in Table 1, the effective heat transfer value of the cross-mixing balancing well underground heat exchanger is $9.22(\mathrm{~W} / \mathrm{m} \cdot \mathrm{K} 0$. As a result of measuring the thermal performance of the ground using two types of underground heat exchangers, we showed that the thermal performance of the cross-mixing balancing well underground heat exchanger was more than three times higher than that of the SCW underground heat exchanger.

Figure 7 illustrates the results of comparing and analyzing SCWs of single wells and two wells and SCWs with bleeding applied. When two wells and bleeding were applied, the thermal performance was improved as compared with that of the existing SCW [23]. This could have been because of the results obtained from Figures 5 and 6, which are similar to the results of the study of Lee et al. [23]. It is estimated that similar results were obtained when comparing the performance of bleed using SCW ground heat exchanger in a single well and two wells. Similar to the cross-mixed balancing well method applied in this study, two wells were used to obtain results that were very similar to the bleeding result.

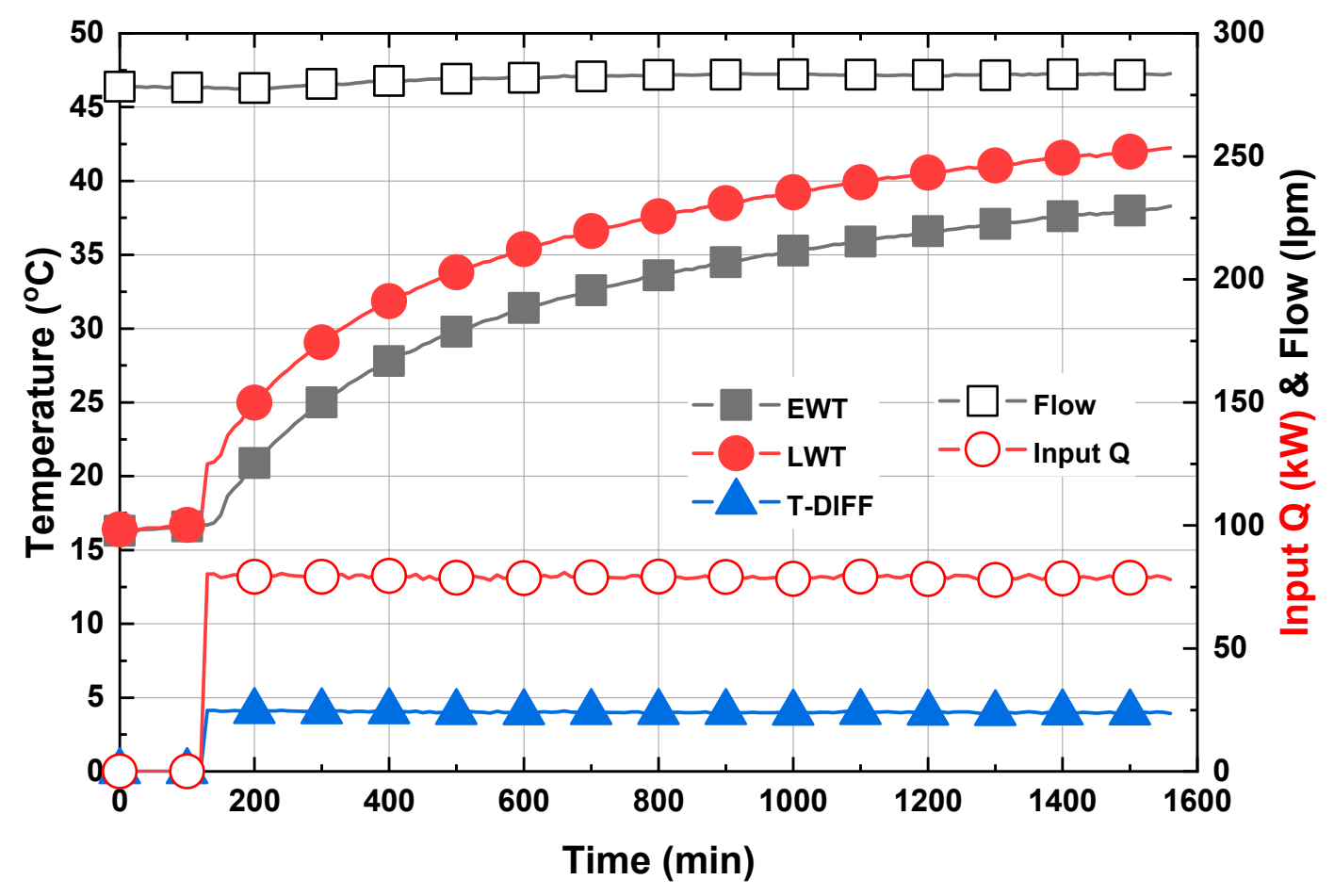

(a)

Figure 5. Cont. 


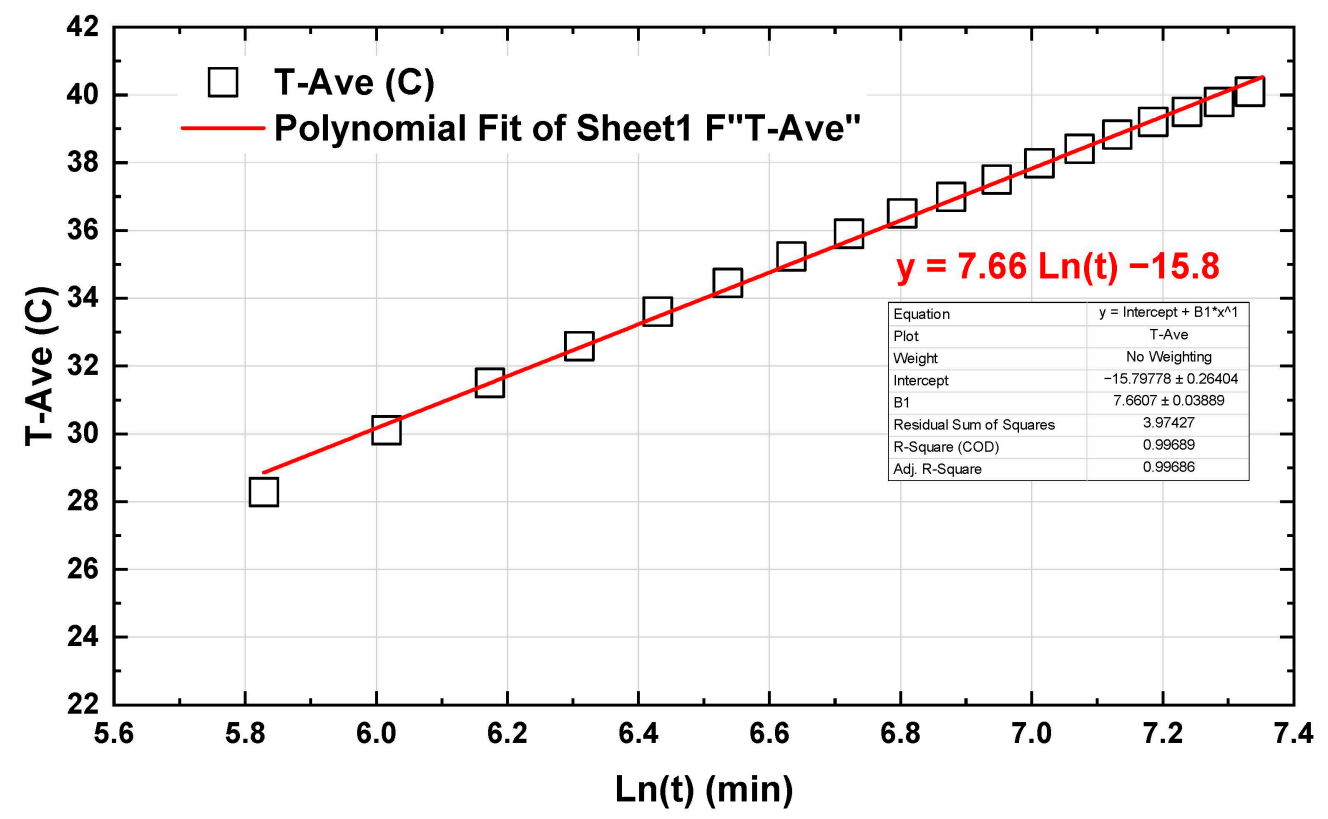

(b)

Figure 5. Characteristics on the thermal performance of an SCW geothermal heat exchanger. (a) Inlet and outlet recirculation water temperature, recirculation water rate and heat injection; (b) Slope of K.

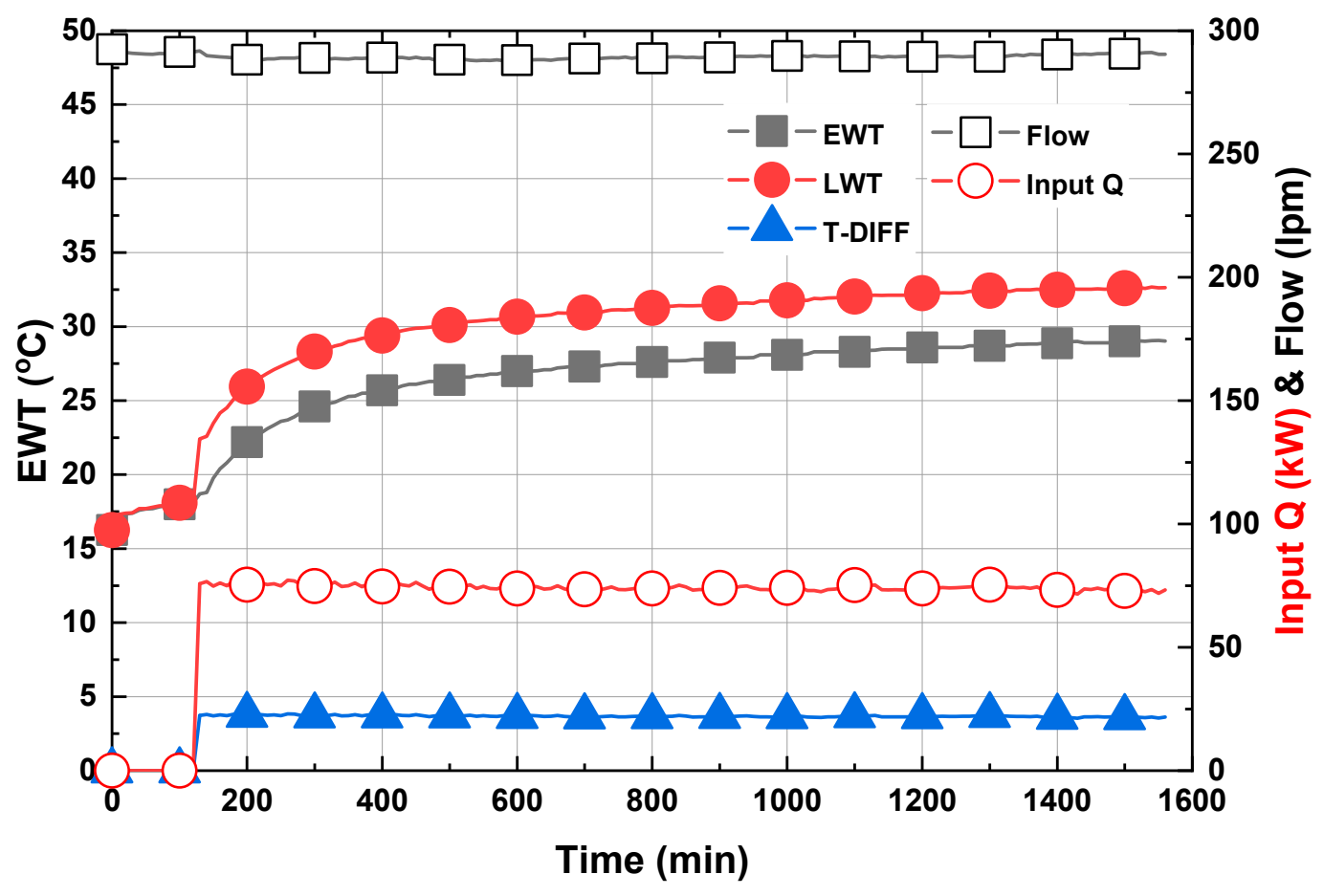

(a)

Figure 6. Cont. 


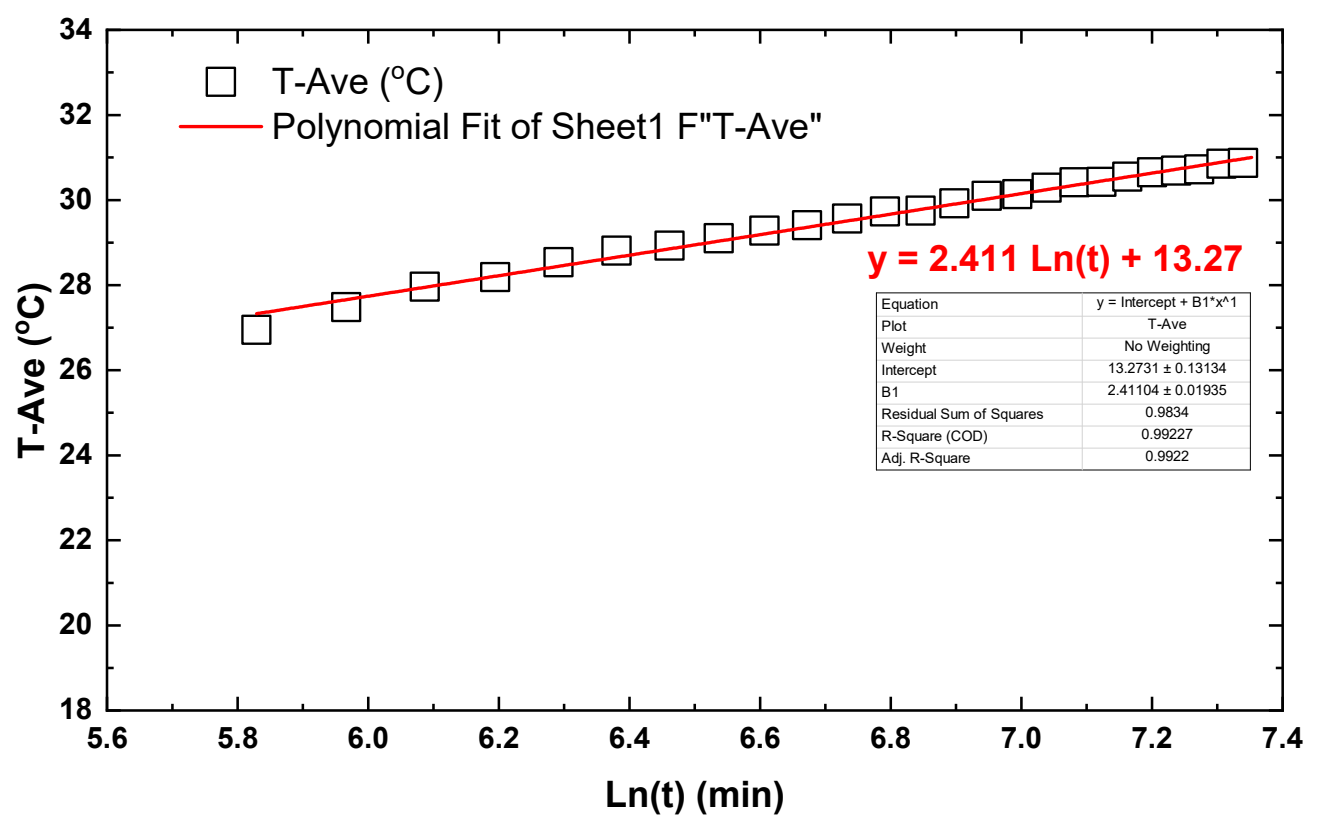

(b)

Figure 6. Characteristics of the thermal performance of cross-mixing balancing well geothermal heat exchanger. (a) Inlet and outlet recirculation water temperature, recirculation water rate, and heat injection; (b) Slope of K.

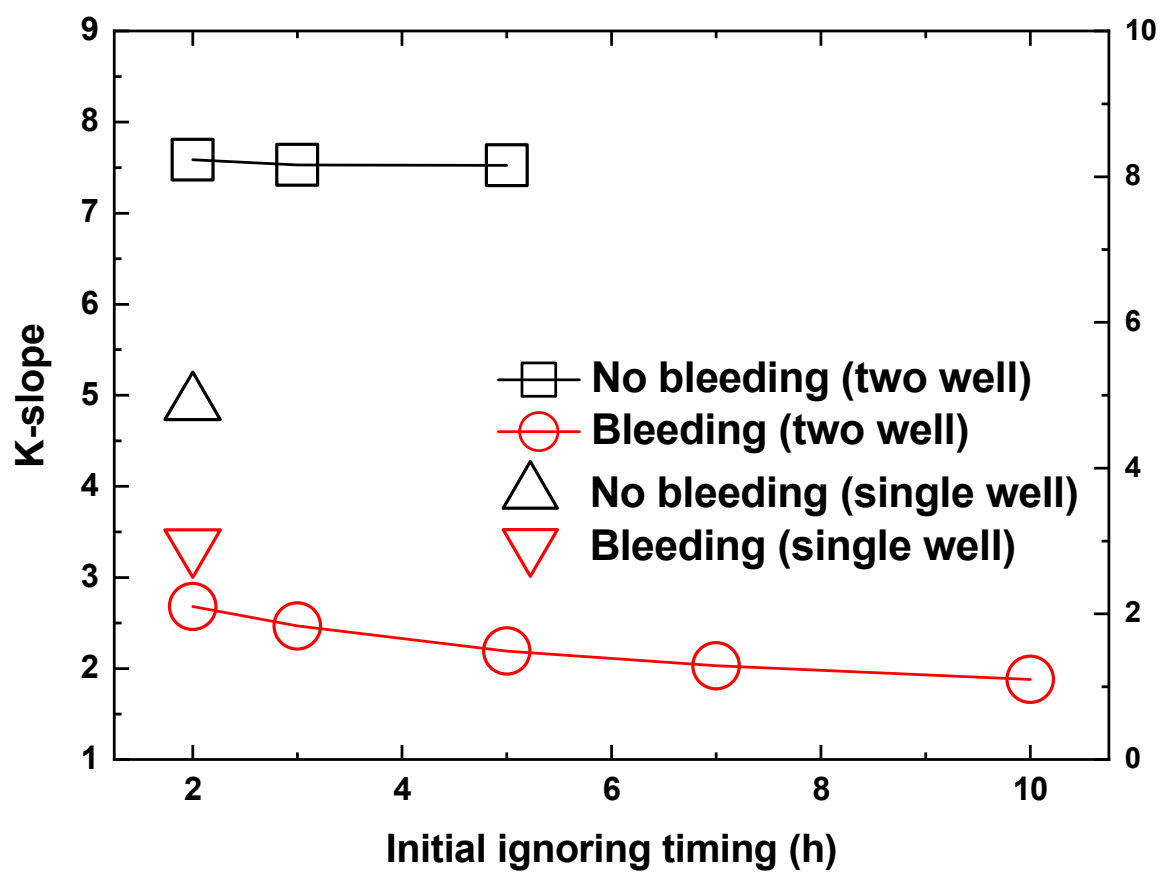

(a)

Figure 7. Cont. 


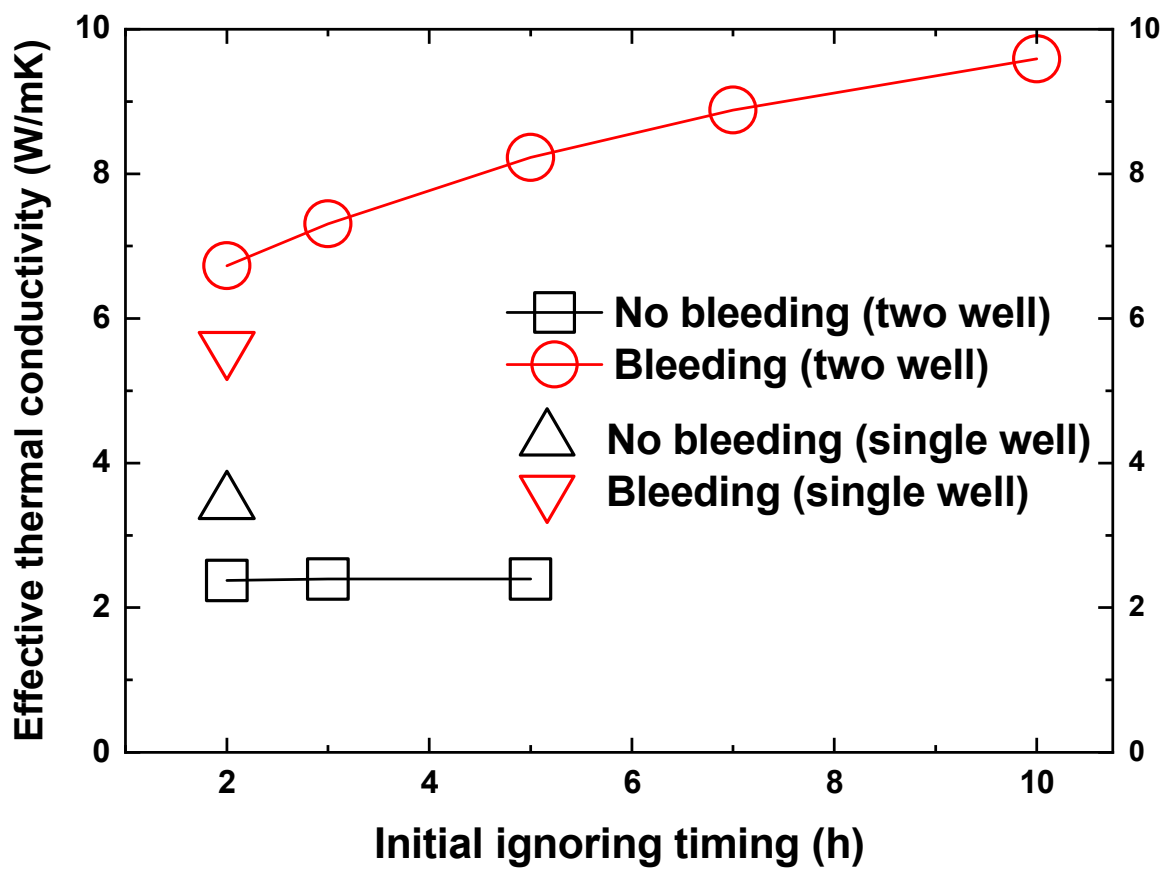

(b)

Figure 7. Effective thermal-conductivity characteristic under no-bleeding and bleeding conditions of the single well- and two-well-type SCW geothermal heat-exchanger system. (a) K-slope; (b) Effective thermal conductivity [23].

Table 3. Calculation of the effective thermal conductivity.

\begin{tabular}{|c|c|c|c|c|c|c|}
\hline SCW Type & $\begin{array}{c}\text { Initial } \\
\text { Temperature }\end{array}$ & $\begin{array}{c}\text { Ave. Diff. of } \\
\text { Temperature between } \\
\text { Inlet and Out Water }\end{array}$ & $\begin{array}{c}\text { Heat } \\
\text { Injection }\end{array}$ & Slope (K) & $\begin{array}{l}\text { Effective Thermal } \\
\text { Conductivity }\end{array}$ & $\begin{array}{l}\text { Ratio of Bleeding } \\
\text { to No Bleeding }\end{array}$ \\
\hline & ${ }^{\circ} \mathrm{C}$ & ${ }^{\circ} \mathrm{C}$ & W & - & $\mathrm{W} / \mathrm{m} \cdot \mathrm{K}$ & $\%$ \\
\hline SCW & 16.51 & 4.01 & 81,000 & 7.66 & 3.075 & - \\
\hline Balancing well & 17.71 & 3.67 & 76,000 & 2.41 & 9.22 & $300 \%$ \\
\hline
\end{tabular}

\subsection{Effective Thermal Conductivity}

Figure 8 shows the results of variation in temperature against the measured time Ln (natural $\log$ ) to evaluate the thermal performance of the SCW ground heat exchanger; the graph is used to obtain the slope of Equation (3). Figure 8a,b presents the thermal load status on the load side in the heating and cooling modes, respectively. The average effective thermal conductivity values of the heating and cooling modes are 5.86 and $3.19 \mathrm{~W} / \mathrm{mK}$, respectively. However, the heating mode shows appropriate thermal performance than the cooling mode. From the results of Figure $8 b$, it is determined that thermal performance is degraded due to heat accumulation by the increase in the temperature of the circulating water on the geothermal side. The results shown in Figure $8 \mathrm{a}$ are assumed to be due to the alleviation of heat accumulation caused by the lower circulated water temperature on the geothermal side. 


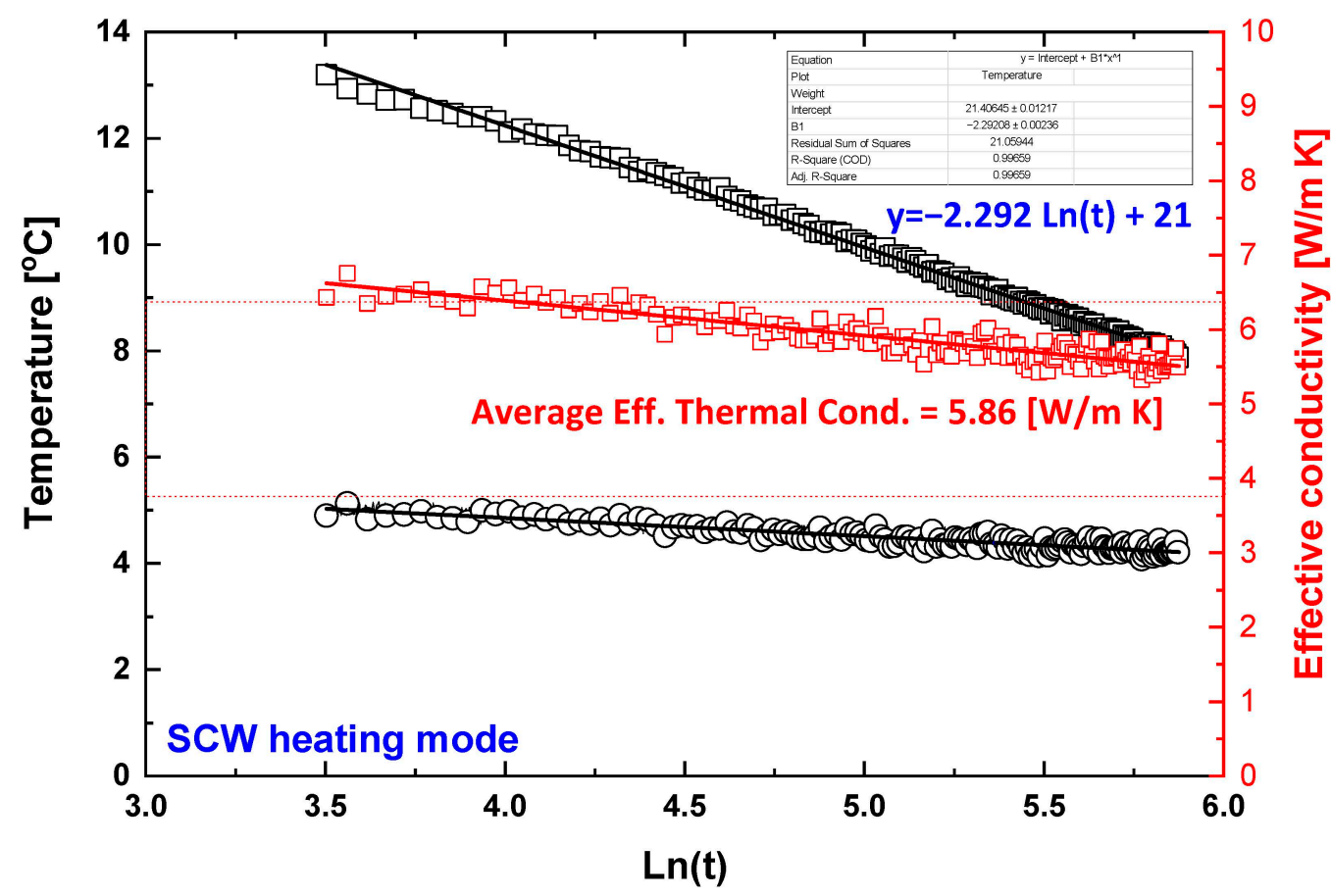

(a) SCW during heating operation

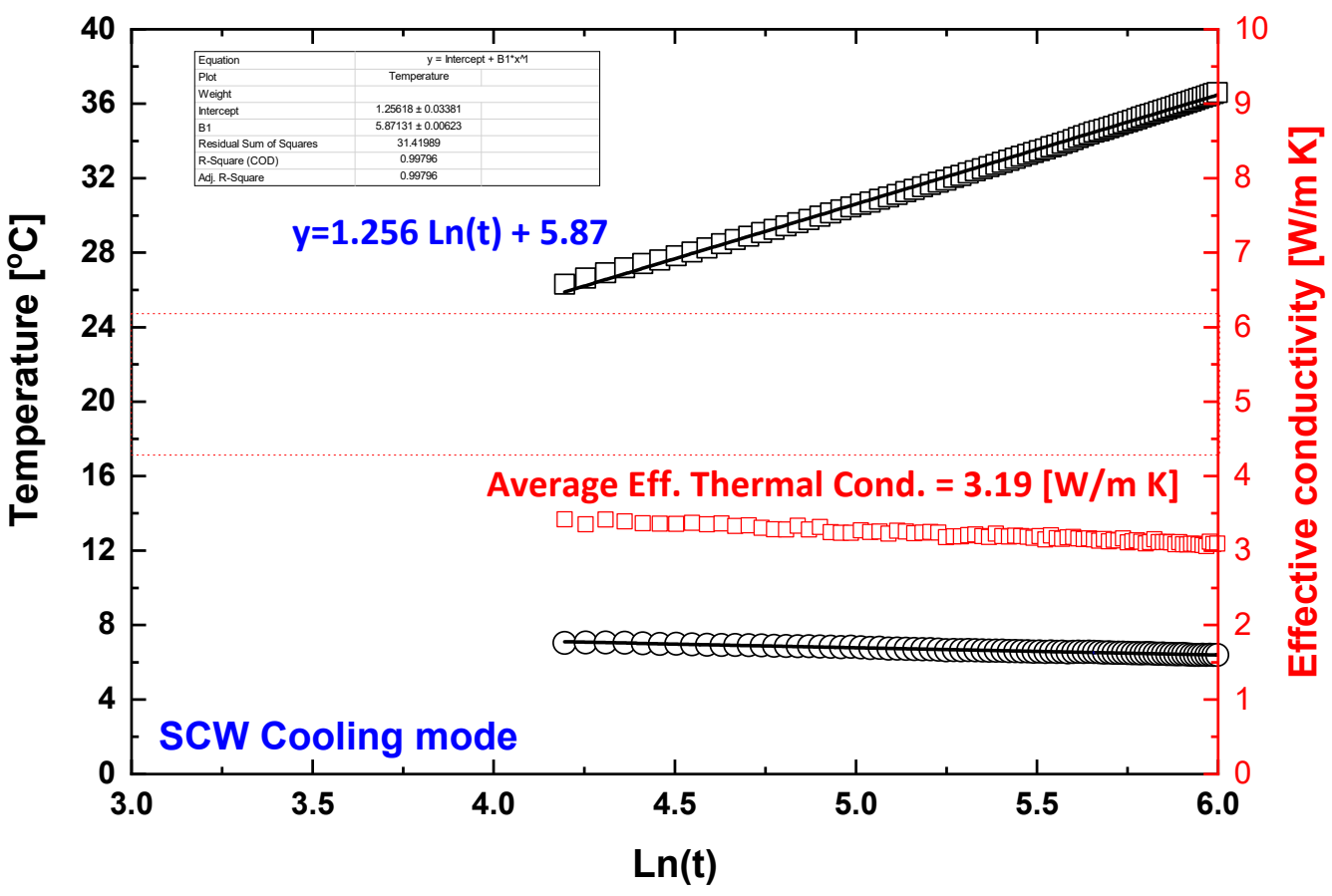

(b) SCW during cooling operation

Figure 8. Characteristics on the average temperature and effective thermal conductivity in the cooling and heating modes using the SCW geothermal heat exchanger. 
Figure 9 presents the result of variation in temperature against the measured time Ln (natural log) to evaluate the thermal performance of the balancing well underground heat exchanger; the graph is used to obtain the slope of Equation (3). Figure 9a,b shows the thermal load status on the load side in the heating and cooling modes, respectively. The slopes of the two modes show conflicting forms caused by the different conditions of the heating and cooling modes. Here, the slope of the temperature over this calculated time was -1.283 and 1.209 , respectively. The effective thermal conductivity values using the line-source expression show the values of 11.3 and $16.2 \mathrm{~W} / \mathrm{mK}$, respectively, during the heating and cooling modes. These results demonstrate the opposite tendency of the results in Figure 5 . The mean effective thermal conductivity shown in Figure 9a indicates a tendency for the value of Figure $9 \mathrm{~b}$ to be large. The possible reason is due to the energy flowing from the outside owing to the low temperature underground water flow along with circulation of water from the well to the low well, which is higher than the natural water level, due to different water levels.

Here, in the case of the balancing well underground heat exchanger, the reason why the thermal conductivity is higher in the cooling mode than the heating mode is because the circulated water temperature on the geothermal side is lower and the heat transfer characteristics are improved due to the inflow of groundwater.

Table 4 presents the result of the comparison and analysis of characteristics of the effective heat map obtained using the results demonstrated in Table 3 and Figures 8 and 9. These results showed that the heating operation for the SCW underground heat exchanger exhibited better thermal conductivity characteristics than the cooling operation. In addition, in the case of a balancing well underground heat exchanger, the cooling operation exhibited excellent thermal conductivity characteristics. As such, the performance was considered to have improved because of the flow of activated groundwater in the ground and rapid heat transfer without heat accumulation. Thus, the balancing well underground heat exchanger showed $24 \%$ improvement in COP as compared with the SCW underground heat exchanger.

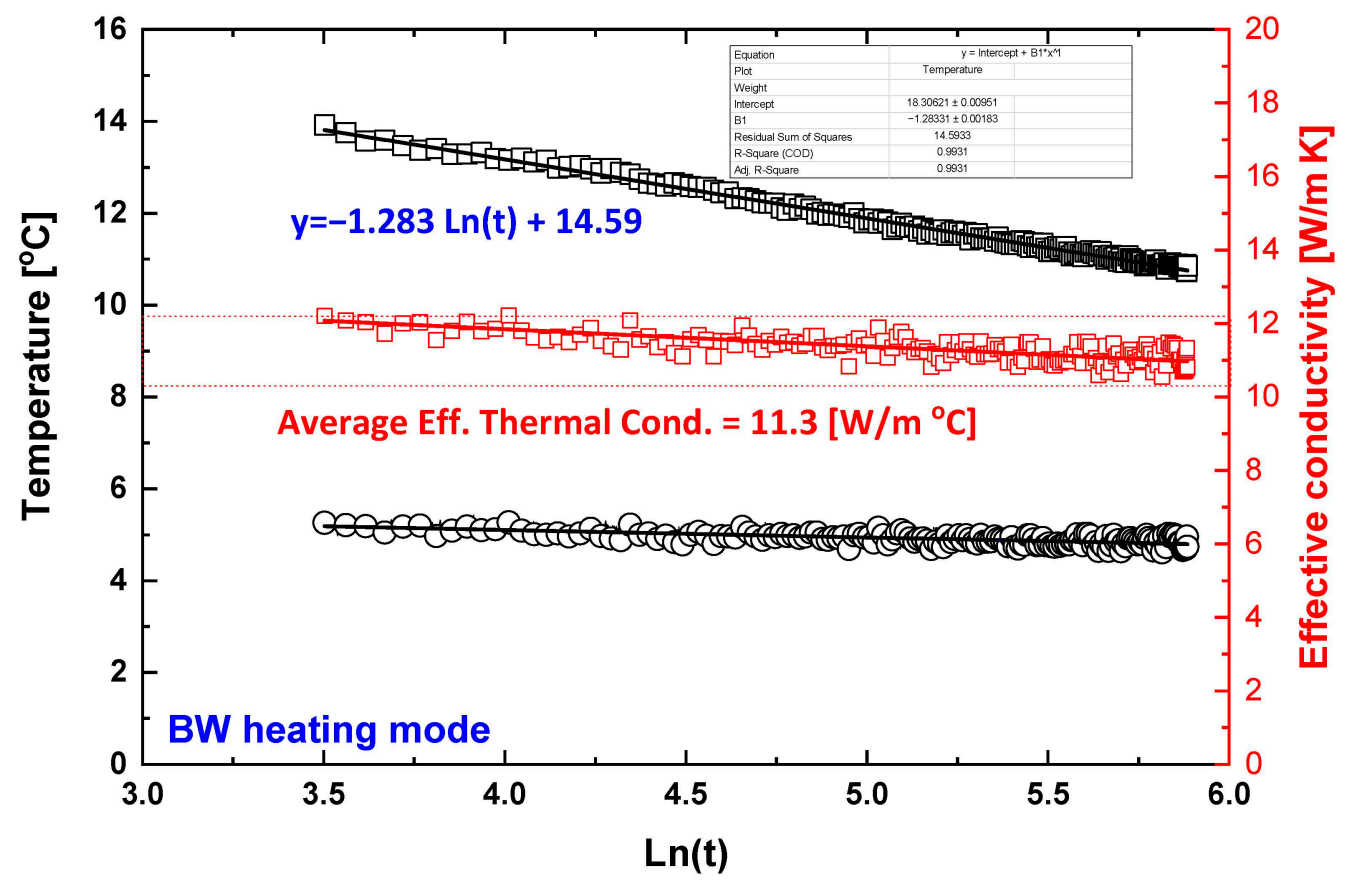

(a) Cross-mixing balancing well during heating operation

Figure 9. Cont. 


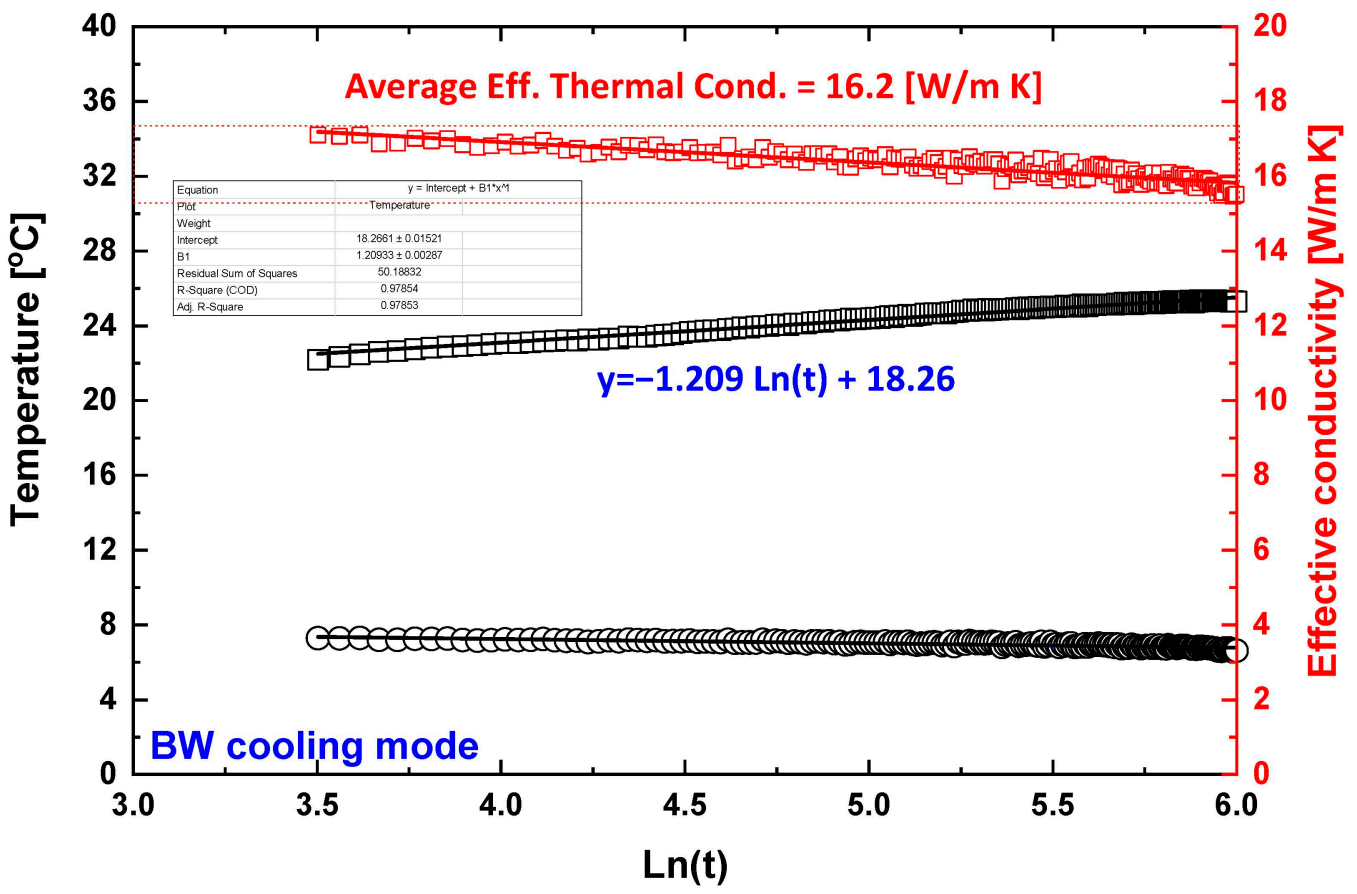

(b) Cross-mixing balancing well during cooling operation

Figure 9. Characteristics of the average temperature and effective thermal conductivity in the cooling and heating modes using the balancing well geothermal heat exchanger.

Table 4. Calculation of the effective thermal conductivity under various conditions.

\begin{tabular}{|c|c|c|c|c|c|c|c|}
\hline SCW Type & Parameters & $\begin{array}{c}\text { Initial } \\
\text { Temperature }\end{array}$ & $\begin{array}{l}\text { Ave. Diff. of Temp. } \\
\text { between Inlet and } \\
\text { Out Water }\end{array}$ & $\begin{array}{c}\text { Heat } \\
\text { Injection }\end{array}$ & Slope (K) & $\begin{array}{c}\text { Effective } \\
\text { Thermal } \\
\text { Conductivity }\end{array}$ & $\begin{array}{c}\text { Ratio of } \\
\text { Bleeding to No } \\
\text { Bleeding }\end{array}$ \\
\hline & & ${ }^{\circ} \mathrm{C}$ & ${ }^{\circ} \mathrm{C}$ & W & - & $\mathrm{W} / \mathrm{m} \cdot \mathrm{K}$ & $\%$ \\
\hline \multirow{2}{*}{ 蕉 } & Single well & 16.51 & 4.01 & 81,000 & 7.66 & 3.075 & - \\
\hline & $\begin{array}{l}\text { Heating mode } \\
\text { (two well) }\end{array}$ & 16.99 & 5.0 & 131,000 & -2.292 & 5.86 & $190 \%$ \\
\hline \multirow{3}{*}{ 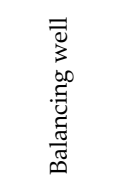 } & Single well & 17.71 & 3.67 & 76,000 & 2.41 & 9.22 & $300 \%$ \\
\hline & $\begin{array}{l}\text { Heating mode } \\
\text { (two well) }\end{array}$ & 16.98 & 5.23 & 137,000 & -1.283 & 11.3 & $367 \%$ \\
\hline & $\begin{array}{l}\text { Cooling mode } \\
\text { (two well) }\end{array}$ & 17.75 & 7.22 & 132,000 & 1.209 & 16.2 & $527 \%$ \\
\hline
\end{tabular}

\subsection{Coefficient of Performance}

Figure 10 shows the temperature distribution of the inlet/outlet (In/Out) on the geothermal and load sides and the total power used and the energy of the SCW ground heat exchanger. Finally, a COP analysis was performed for each mode. Consequently, the heating mode demonstrated in Figure 10b reveals a stable increase in the change in the ground initial temperature as compared with the SCW cooling mode demonstrated in Figure 10a.

Using a cross-mixed balancing well underground heat exchanger, a COP analysis was performed by comparing the temperature of the ground In/Out and In/Out for the heating and cooling modes, as well as the amount of power used to operate the system. The results are shown in Figure 8, which shows characteristics similar to those shown in Figure 10. However, the comparison of the temperature distribution characteristics of the underground and load sides under cooling conditions in Figures 10a and 11a demonstrate that, in the case of SCW ground heat exchangers shown in Figure 10a, 
the cyclical water temperature on the ground increases more as compared with the cross-mixed balancing well underground heat exchangers shown in Figure 11a. Meanwhile, the cross-mixed balancing well heat exchanger shows that the temperature of circulating water on the ground does not increase rapidly. This is due to the activation of the underground aquifer by water level difference owing to the difference in the number of cycles returned to the two wells when using the cross-mixed balancing well. In addition, the improvement of the flow of the underground aquifer to improve the efficiency of the heat exchanger and the ability to recover the temperature of the underground circulating water is considered to be the causes of this increase. Hence, it is believed that heat transfer performance can be improved by disturbing the physical fluids and optimizing the amount of water in the pit through the control of the water level difference and cross operating by utilizing the underground heat exchanger applied with the cross-mixed balancing well technique. Furthermore, these technologies, along with the application of groundwater filtering devices, are expected to prevent dust.
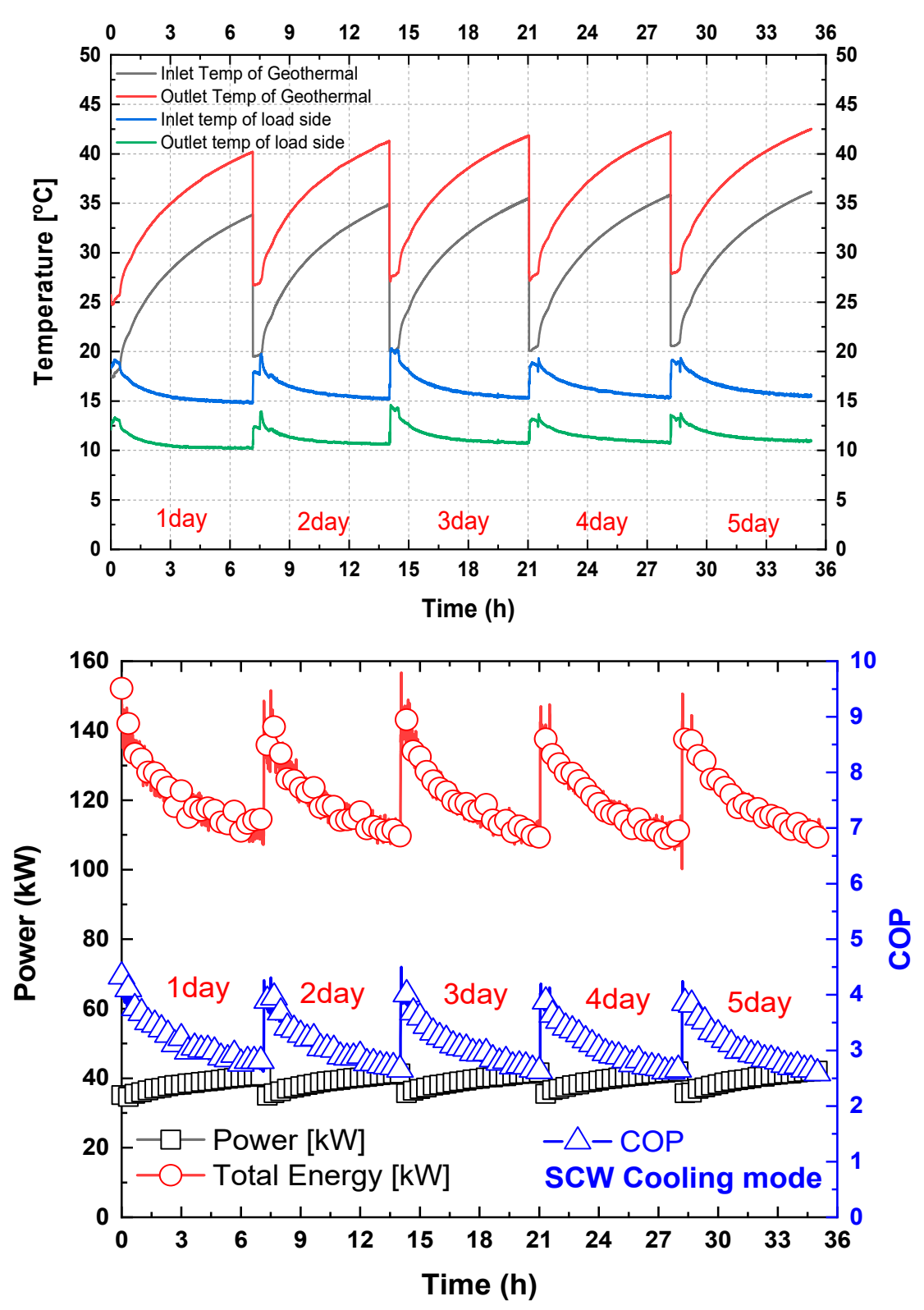

(a) SCW during cooling operation

Figure 10. Cont. 

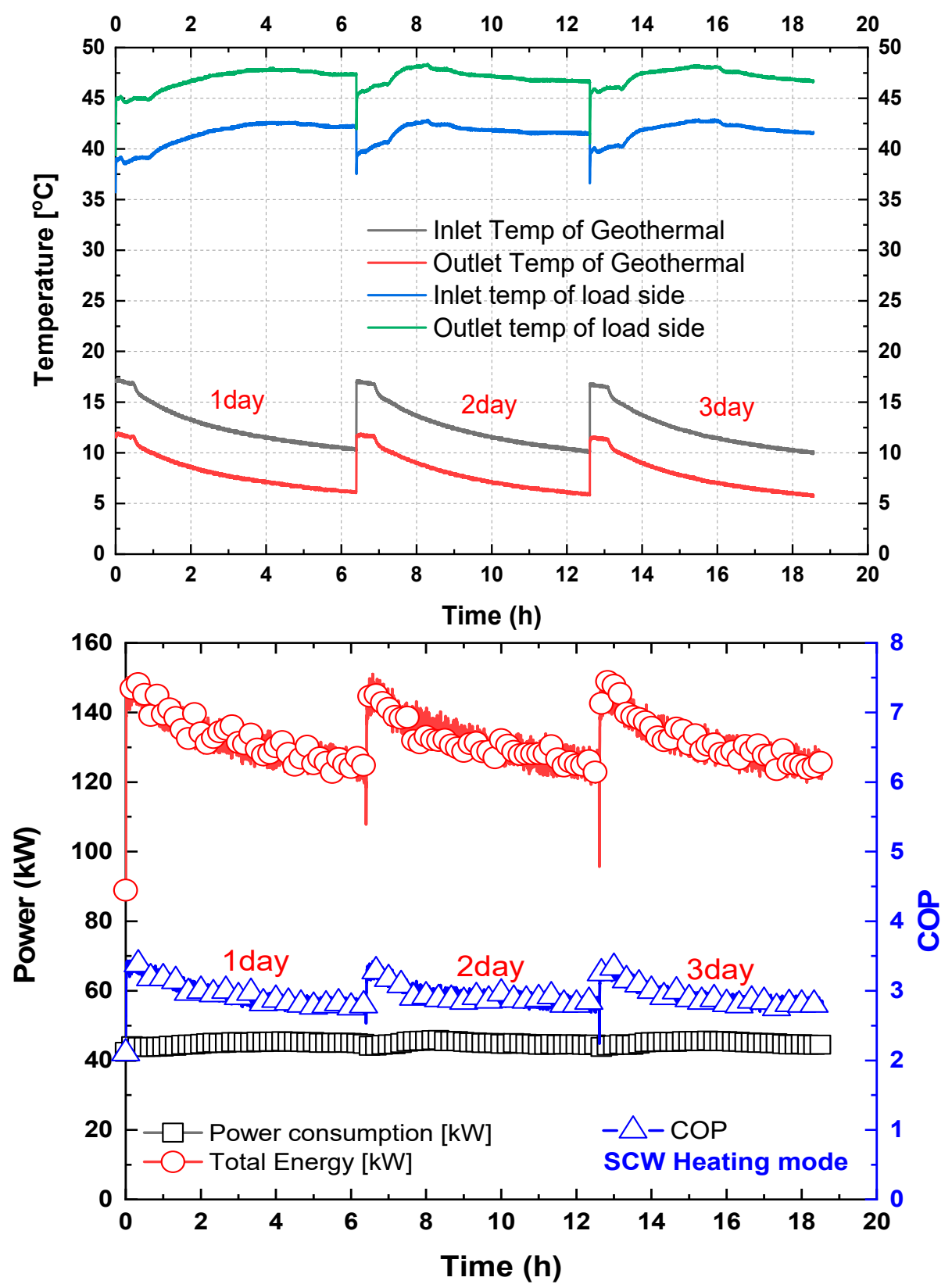

(b) SCW during heating operation

Figure 10. Temperature distribution of the in/out on the geothermal and load sides of the SCW ground heat exchanger.

The cooling and heating modes shown in Figure 11a,b, respectively, were operated to compare the $\mathrm{COP}$, and it was confirmed that the cross-mixed balancing well underground heat exchanger performed somewhat better during the cooling mode than during the heating mode.

Tables 5 and 6 present the results for the analysis of the ground and load immediate temperature, total power used, power consumption, and COP characteristics of the SCW and balancing well underground heat exchangers. Table 5 shows the average COP of the SCW underground heater in cooling and heating operations to be 3.05 and $2.92 \mathrm{COP}$, respectively. Table 6 presents these values to be 3.76 and 3.27, respectively. The COP of two types of underground heat exchangers indicates a better performance of cross-mixed balancing well underground heat exchangers as compared with the SCW 
type. It is believed that reflecting these systems in the design would reduce construction costs and improve the overall performance.
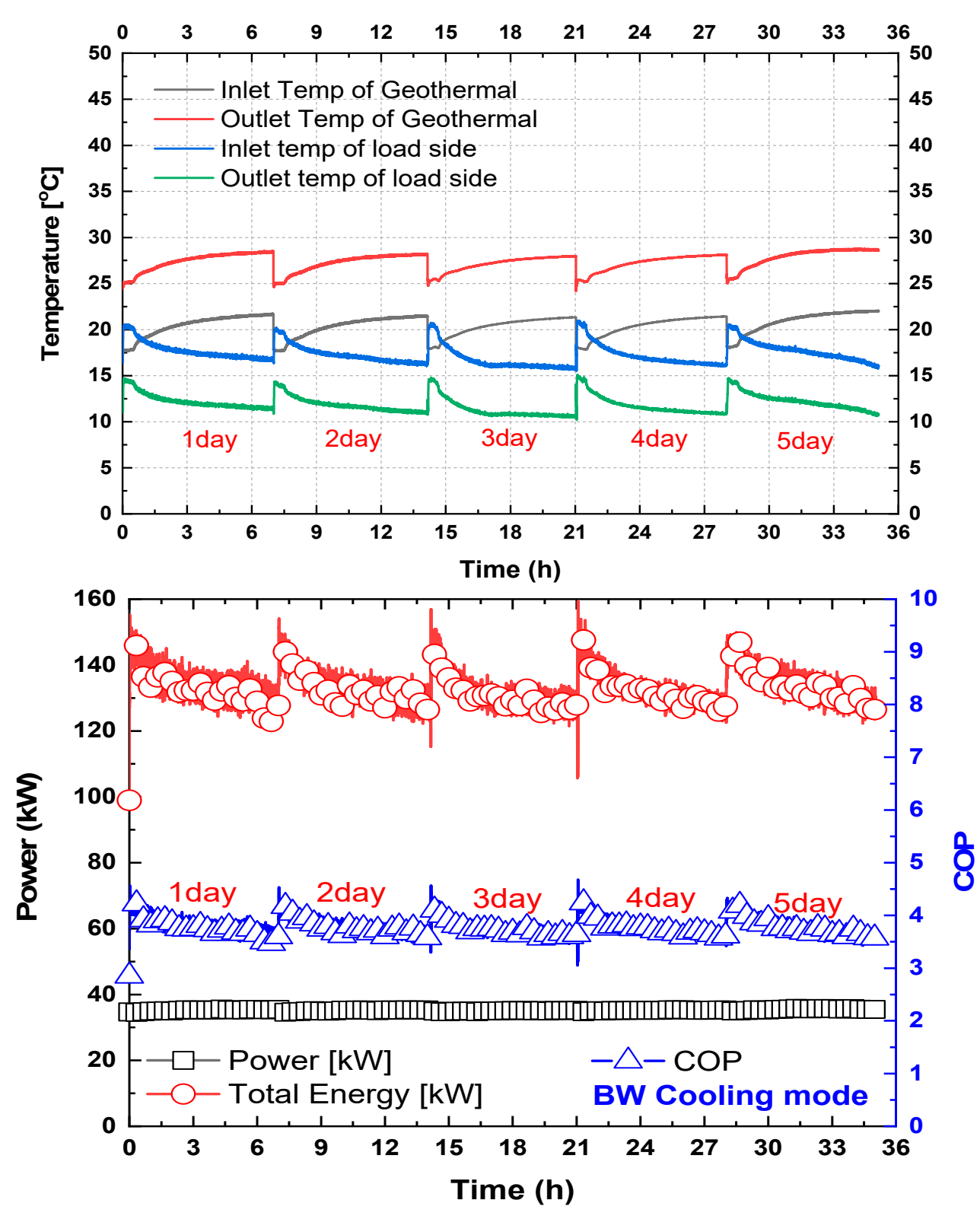

(a) Balancing well during cooling operation

Figure 11. Cont. 

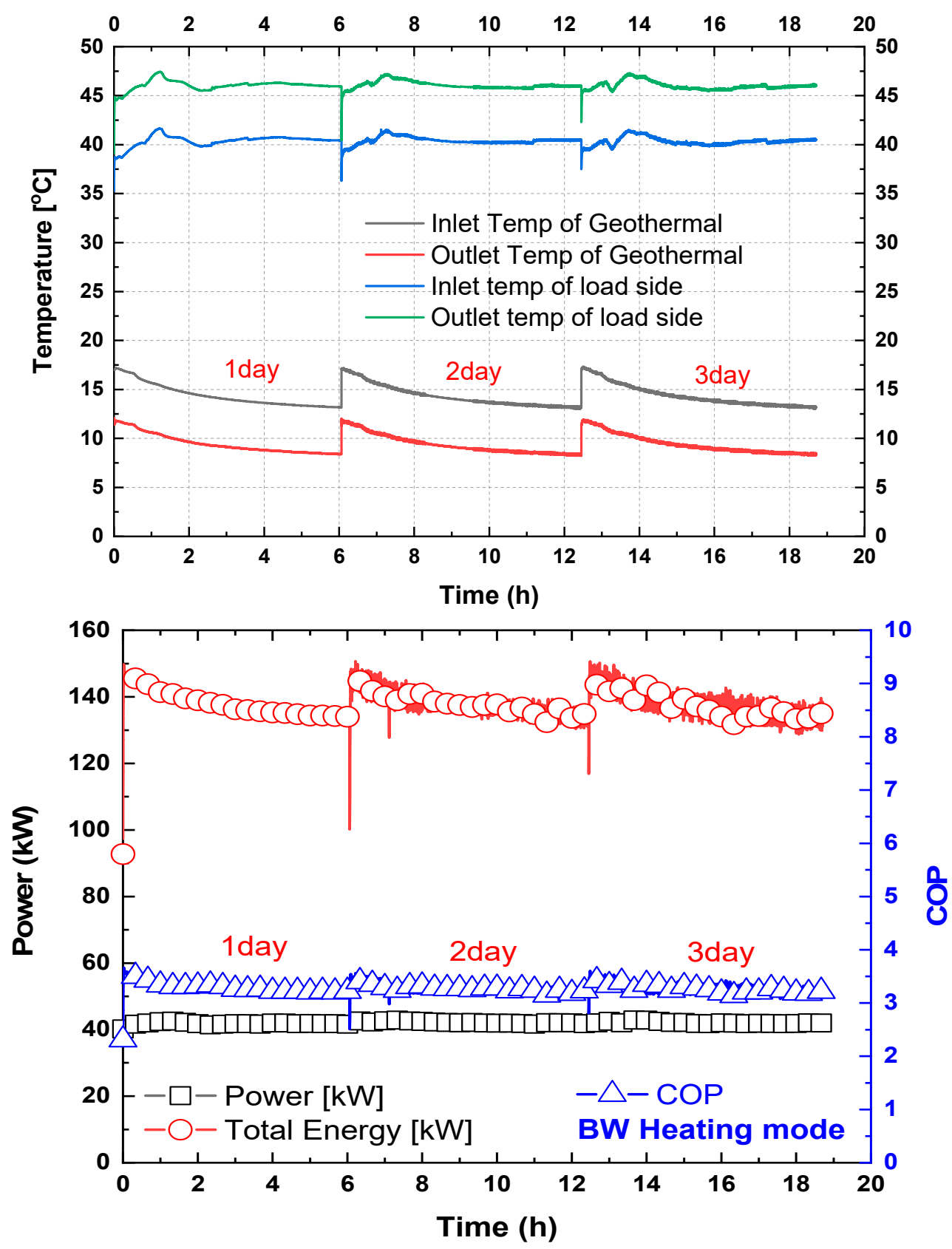

(b) Balancing well during heating operation

Figure 11. Balancing well geothermal heat exchanger method for analyzing the temperature of the In/Out on the geothermal side and the temperature distribution of the In/Out on the load side.

Tables 7 and 8 present the results of the analysis of the initial temperature and COP characteristics of the SCW and balancing well underground heat exchangers, respectively. Table 7 presents that the stable characteristic of the balancing well underground heat exchanger is more than 10 times as a result of distributed distribution in the distribution of initial temperature. The results indicate that the ground water temperature of the balancing well underground heat exchanger is more stable than that of the SCW underground heat exchanger, and thus the system performance is stable. Table 8 shows the improvement in the COP of the balanced well underground heat exchanger was more than $23 \%$ 
over the SCW type. It is believed that this improvement has increased the circulation and heat transfer effects of the underground water on the ground through cross mixing.

Table 5. Characteristics of the initial groundwater temperature of SCW geothermal heat exchanger.

\begin{tabular}{|c|c|c|c|c|c|c|c|c|c|c|}
\hline & \multirow{2}{*}{$\begin{array}{l}\text { Initial Ground } \\
\text { Water Temp. }\end{array}$} & \multicolumn{3}{|c|}{ Temperature of Geothermal Side } & \multicolumn{3}{|c|}{ Temperature of Load Side } & \multirow{2}{*}{$\begin{array}{l}\text { Total } \\
\text { Power }\end{array}$} & \multirow{2}{*}{$\begin{array}{c}\text { Power } \\
\text { Consumption }\end{array}$} & \multirow{2}{*}{ COP } \\
\hline & & Inlet & Outlet & Flow Rate & Inlet & Outlet & Flow Rate & & & \\
\hline NO/Units & ${ }^{\circ} \mathrm{C}$ & ${ }^{\circ} \mathrm{C}$ & ${ }^{\circ} \mathbf{C}$ & LPM & ${ }^{\circ} \mathrm{C}$ & ${ }^{\circ} \mathrm{C}$ & LPM & kW & kW & $(-)$ \\
\hline 1 & 17.72 & 28.37 & 35.08 & 305.69 & 15.60 & 10.63 & 346.39 & 120.11 & 38.35 & 3.13 \\
\hline 2 & 19.94 & 29.90 & 36.62 & 304.75 & 15.60 & 11.10 & 346.68 & 119.10 & 39.03 & 3.05 \\
\hline 3 & 19.98 & 30.45 & 37.14 & 306.05 & 16.28 & 11.35 & 346.58 & 119.06 & 39.29 & 3.03 \\
\hline Average & 19.65 & 30.07 & 36.77 & 305.38 & 16.06 & 11.21 & 347.08 & 119.46 & 39.19 & 3.05 \\
\hline \multicolumn{11}{|c|}{ SCW geothermal heat exchanger at heating mode } \\
\hline 1 & 16.99 & 12.30 & 7.77 & 324.62 & 41.64 & 47.03 & 349.12 & 131.26 & 44.89 & 2.92 \\
\hline 2 & 16.15 & 12.40 & 7.87 & 324.31 & 41.85 & 47.25 & 349.12 & 131.65 & 45.01 & 2.92 \\
\hline 3 & 15.84 & 12.12 & 7.62 & 324.55 & 41.99 & 47.37 & 349.29 & 131.01 & 45.01 & 2.92 \\
\hline
\end{tabular}

Table 6. Characteristics of the initial ground-water temperature of a balancing well geothermal heat exchanger.

\begin{tabular}{|c|c|c|c|c|c|c|c|c|c|c|}
\hline & \multirow{2}{*}{$\begin{array}{l}\text { Initial Ground } \\
\text { Water Temp. }\end{array}$} & \multicolumn{3}{|c|}{ Temperature of Geothermal Side } & \multicolumn{3}{|c|}{ Temperature of Load Side } & \multirow{2}{*}{$\begin{array}{l}\text { Total } \\
\text { Power }\end{array}$} & \multirow{2}{*}{$\begin{array}{c}\text { Power } \\
\text { Consumption }\end{array}$} & \multirow{2}{*}{ COP } \\
\hline & & Inlet & Outlet & Flow Rate & Inlet & Outlet & Flow Rate & & & \\
\hline NO/Units & ${ }^{\circ} \mathrm{C}$ & ${ }^{\circ} \mathrm{C}$ & ${ }^{\circ} \mathrm{C}$ & LPM & ${ }^{\circ} \mathrm{C}$ & ${ }^{\circ} \mathrm{C}$ & LPM & kW & kW & $(-)$ \\
\hline 1 & 17.75 & 20.61 & 27.56 & 317.81 & 17.61 & 12.14 & 349.69 & 133.55 & 35.26 & 3.79 \\
\hline 2 & 17.63 & 20.44 & 27.33 & 318.14 & 17.22 & 11.79 & 349.47 & 132.58 & 35.13 & 3.77 \\
\hline 3 & 17.91 & 20.44 & 27.21 & 318.76 & 16.49 & 11.13 & 349.14 & 130.54 & 35.00 & 3.73 \\
\hline Average & 17.75 & 20.49 & 27.35 & 318.47 & 17.07 & 11.65 & 349.51 & 132.22 & 35.15 & 3.76 \\
\hline \multicolumn{11}{|c|}{ Balancing well geothermal heat exchanger in heating mode } \\
\hline 1 & 16.98 & 14.28 & 9.36 & 319.20 & 40.53 & 46.19 & 348.31 & 137.48 & 41.91 & 3.28 \\
\hline 2 & 16.85 & 14.26 & 9.33 & 318.75 & 40.47 & 46.14 & 348.60 & 137.95 & 41.91 & 3.27 \\
\hline
\end{tabular}

Table 7. Distribution of standard deviation of initial ground-water temperature in cooling and heating modes.

\begin{tabular}{ccccc}
\hline \multirow{2}{*}{ Initial Ground-Water Temperature } & \multicolumn{2}{c}{ Cooling Operation } & \multicolumn{2}{c}{ Heating Operation } \\
\cline { 2 - 5 } & SCW & Balancing Well & SCW & Balancing Well \\
\hline 1 & 17.72 & 17.75 & 16.99 & 16.98 \\
2 & 19.94 & 17.63 & 16.15 & 16.85 \\
3 & 19.98 & 17.91 & 15.84 & 16.85 \\
4 & 20.09 & 17.63 & & \\
5 & 20.54 & 17.84 & & $\mathbf{0 . 0 8}$ \\
\hline
\end{tabular}

Table 8. Coefficient of performance (COP) of SCW and cross-mixing balancing well geothermal heat exchanger in heating and cooling modes.

\begin{tabular}{ccccccc}
\hline \multirow{2}{*}{ COP Performance Coefficient } & \multicolumn{3}{c}{ Cooling Operation } & \multicolumn{3}{c}{ Heating Operation } \\
\cline { 2 - 7 } & SCW & Balancing Well & Remarks & SCW & Balancing Well & Remarks \\
\hline minimum & 2.58 & 3.45 & & 2.08 & 2.21 & \\
maximum & 3.96 & 4.29 & & 3.44 & 3.66 & $\mathbf{1 2} \% \uparrow$ \\
\hline Average & $\mathbf{3 . 0 5}$ & $\mathbf{3 . 7 6}$ & $\mathbf{2 3} \% \uparrow$ & $\mathbf{2 . 9 2}$ & $\mathbf{3 . 2 7}$ & $\mathbf{1 2 7}$ \\
\hline
\end{tabular}


The thermal conductivity of the geothermal heat exchanger for the measured geology always has a constant value. The reason for this is thought to be that the effective thermal conductivity is determined by the energy transfer of circulating water, which is a medium for heat transfer. In this study, the thermal conductivity of the balancing well underground heat exchanger is improved because it utilizes the flow of groundwater by controlling the bleeding rate in different well holes to increase the flow of underground water in the ground. This same effect was obtained, which was similar to the effective thermal conductivity characteristics according to the bleeding rate. Recharge technology through groundwater level difference control can be maximized through artificial recharge control through proportional control valves and flow meters.

Therefore, it was derived that the overall COP was improved due to a decrease in the amount of heat injected due to the energy introduced from the groundwater in the ground. In addition, it is judged that the improvement was due to the improvement of the heat exchange efficiency through the improvement of the underground aquifer flow and the increase in the temperature restoration ability of the underground circulating water.

\subsection{Thermal Environment of the Groundwater Temperature}

Figure 12 shows the results of analyzing the thermal environment characteristics of the ground water through the cross mixing of the SCW and balancing well methods. Figure 12a shows the characteristics of the circulating water intake temperature, circulation flow rate, bleed flow rate, input and exit temperature difference, and injected heat caused by the change to the balancing well method from the SCW method after $24 \mathrm{~h}$ of operation. The SCW method initially shows a continuous increase in the temperature of the In/Out during operation. However, utilizing the SCW method instead of the balancing well method results in a decrease in temperature difference between the inlet and out temperatures of the circulating water. The possible reason is the activation of the underground aquifer by the water level difference of the well by the injected bleed flow and the activation of the flow of the underground aquifer. Consequently, the temperature recovery of the underground circulating water might increase. Figure $12 \mathrm{~b}$ shows the results of the circulation water temperature, circulation flow rate, bleed flow rate, and injection heat, due to utilization of the SCW method, instead of the balancing well operation, after $24 \mathrm{~h}$ of operation. When operating the balancing well method, the temperature difference between the inlet and exit temperatures of the circulating water is observed to be slightly higher than that shown in Figure 12a. However, when changing from the balancing well method to the SCW method of operation, the temperature of the In/Out increases rapidly. Through this technique, it is deemed that the heat accumulation phenomenon occurred because of the increase in the temperature of the circulating water in the ground. As shown in Table 4, when driving balancing well, the thermal efficiency increases more than that of the SCW, and the thermal environmental conditions of the ground water are optimized, which can be a condition for long-term operation. 

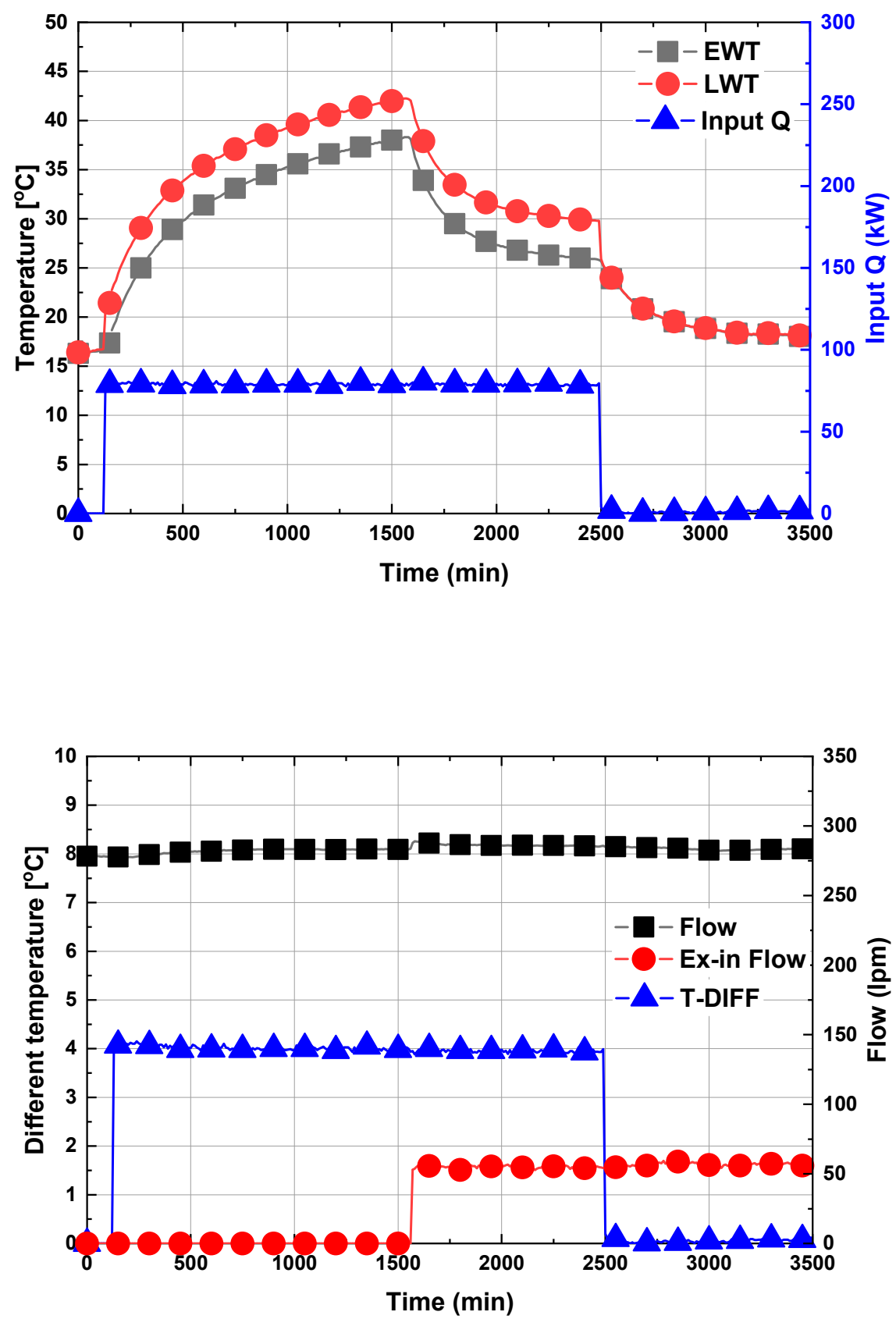

(a) SCW operation $\rightarrow$ balancing well operation

Figure 12. Cont. 

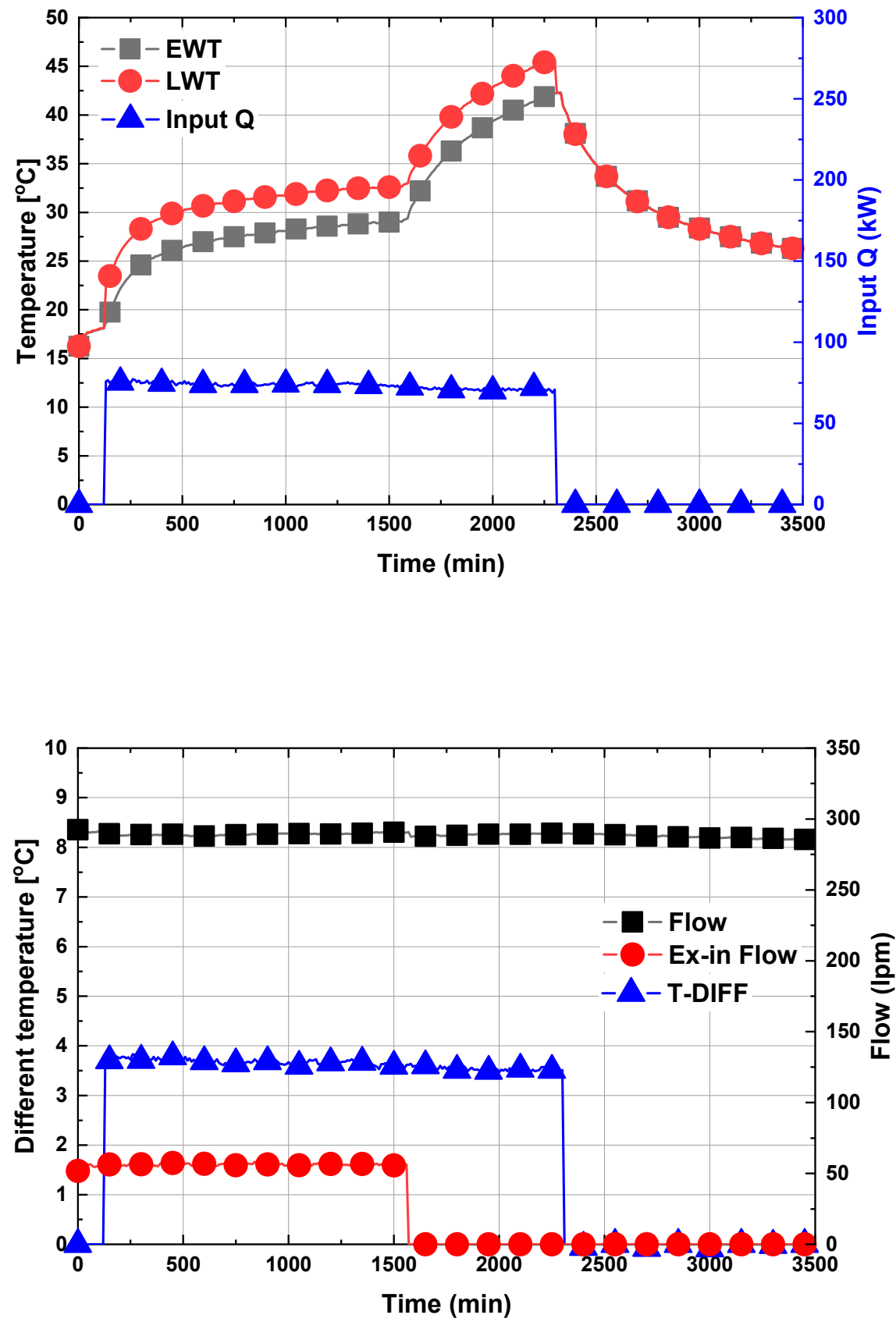

(b) Balancing well operation $\rightarrow$ SCW operation

Figure 12. Operating characteristics of the SCW and cross-mixing balancing well geothermal heat exchanger affecting the thermal environmental characteristics of the ground.

\section{Conclusions}

The results of the analysis of the thermal environment and COP characteristics during heating and cooling operations using SCW and cross-mixed balancing well underground heat exchangers are presented as follows:

1. Using the SCW and cross-mixing balancing well underground heat exchanger, the effective thermal conductivity characteristics and COP characteristics during heating and cooling modes were compared and analyzed. Thus, the cross-mixing balancing well underground heat exchanger exhibited more effective thermal conductivity than the SCW underground heat exchanger with a 
high COP. Therefore, we assumed that the performance was improved because it utilized the groundwater flow in contrast to the SCW.

2. The effective heat transfer value of the cross-mixing balancing well underground heat exchanger was $9.22(\mathrm{~W} / \mathrm{m} \cdot \mathrm{K})$. The thermal performance of the ground was measured using two types of underground heat exchangers; the results showed that the thermal performance of the cross-mixing balancing well underground heat exchanger was more than three times higher than that of the SCW underground heat exchanger.

3. In the case of SCW geothermal heat exchanger, the average effective thermal conductivity values of the heating and cooling modes were 5.86 and $3.19 \mathrm{~W} / \mathrm{mK}$, respectively. In case of balancing well cross-mixing geothermal heat exchanger, the effective thermal conductivity values using the line-source expression were 11.3 and $16.2 \mathrm{~W} / \mathrm{mK}$, respectively, during the heating and cooling modes. A comparison of the SCW and cross mixing balancing well geothermal heat exchanger showed that the balancing well system has much better performance than SCW.

4. The result of comparing and analyzing the characteristics of the effective heat map using the results of SCW and balancing well system showed that the heating operation for the SCW underground heat exchanger had better thermal conductivity characteristics than the cooling operation. In addition, in the case of a balancing well underground heat exchanger, the cooling operation showed suitable thermal conductivity characteristics. As such, it is considered that the improvement in performance was caused by the flow of activated groundwater in the ground and rapid heat transfer without heat accumulation.

5. The COP of two types of geothermal heat exchangers indicates a better performance of cross-mixed balancing well underground heat exchangers as compared with the SCW type. It is believed that reflecting these systems in the design would reduce the construction costs and improve the overall performance.

6. The results of analysis of the thermal environment characteristics of the ground water through the cross mixing of the SCW and balancing well methods showed that, when driving the balancing well, the thermal efficiency of cross-mixing balancing well system increases more than that of the SCW, optimizing the thermal environmental conditions of the ground water, which can be a condition for long-term operation.

Author Contributions: Conceptualization, K.L.; methodology, K.L.; investigation, M.L.; data curation, C.L.; writing - original draft preparation, C.L.; writing-review and editing, C.L. All authors have read and agreed to the published version of the manuscript.

Funding: This work was supported by the National Research Foundation of Korea (NRF) grant funded by the Korea government (NRF-2018R1D1A1B07049390).

Conflicts of Interest: The authors declare no conflict of interest.

\section{References}

1. Seo, Y.; Seo, U.-J. Ground source heat pump (GSHP) systems for horticulture greenhouses adjacent to highway interchanges: A case study in South Korea. Renew. Sustain. Energy Rev. 2021, 135, 110194. [CrossRef]

2. KEMCO, NR GT 101: Water-to-Water Ground Source Heat Pump; Korea Energy Management Cooperation: Gyeonggi-do, Korea, 2008.

3. KEMCO, NR GT 102: Water-to-Air Ground Source Heat Pump; Korea Energy Management Cooperation: Gyeonggi-do, Korea, 2008.

4. KEMCO, NR GT 103: Water-to-Air Ground Source Multi-Heat Pump; Korea Energy Management Cooperation: Gyeonggi-do, Korea, 2008.

5. International Standardization Organization. International Standard, ISO 13256-1: Water-Source Heat Pumps-Testing and Rating for Performance-Part. 1. Water-to-Air and Brine-to-Air Heat Pumps; International Standardization Organization: Geneva, Switzerland, 1998. 
6. International Standardization Organization. International Standard, ISO 13256-2: Water-Source Heat Pumps-Testing and Rating for Performance-Part. 2. Water-to-Water and Brine-to-Water Heat Pumps; International Standardization Organization: Geneva, Switzerland, 1998.

7. Kim, M.J.; Choi, C.H.; Jeon, J.U. A study on the KS (Korea Standard) of SCW type ground heat exchanger-ground source heat pump system. Korea Acad. Ind. Coop. Soc. 2013, 3, 22-30.

8. Chang, K.S.; Kim, M.J.; Kim, Y.J. An experimental study on the thermal performance evaluation of SCW ground heat exchanger. Int. J. Air-Cond. Refrig. 2017, 25, 1750006. [CrossRef]

9. Gozgor, G.; Mahalik, M.K.; Demir, E.; Padhan, H. The impact of economic globalization on renewable energy in the OECD countries. Energy Policy 2020, 139, 111365. [CrossRef]

10. Sanner, B.; Hellström, G.; Spitler, J.; Gehlin, S. More than 15 years of mobile thermal response test-A summary of experiences and prospects. In Proceedings of the European Geothermal Congress, Pisa, Italy, 3-7 June 2013.

11. Beier, R.A.; Smith, M.D.; Spitler, J.D. Reference data sets for vertical borehole ground heat exchanger models and thermal response test analysis. Geothermics 2011, 40, 79-85. [CrossRef]

12. Chang, K.-S.; Kim, M.J. A study on the heat transfer characteristics of various construction of SCW type ground heat exchanger. Korean J. Air-Cond. Refrig. Eng. 2014, 26, 460-466. [CrossRef]

13. Gustafsson, A.-M.; Westerlund, L. Multi-injection rate thermal response test in groundwater filled borehole heat exchanger. Renew. Energy 2010, 35, 1061-1070. [CrossRef]

14. Raymond, J.; Therrien, R.; Gosselin, L. Borehole temperature evolution during thermal response tests. Geothermics 2011, 40, 69-78. [CrossRef]

15. Chang, K.S.; Kim, M.J. Analysis and thermal response test for vertical ground heat exchanger with two U-loop configuration. Int. J. Energy Res. 2016, 40, 189-197. [CrossRef]

16. Rivera, J.A.; Blum, P.; Bayer, P. A finite line source model with Cauchy-type top boundary conditions for simulating near surface effects on borehole heat exchangers. Energy 2016, 98, 50-63. [CrossRef]

17. Chang, J.H.; Park, D.H.; Park, S.S.; Na, S.M. Evaluation of application of effective hydraulic conductivity in SCW ground heat pump system. J. Korean Geo-Environ. Soc. 2010, 141-146.

18. Jang, K.S.; Kim, M.J. An analysis on the bleeding effect of SCW ground heat exchanger using thermal response test data. Korea Acad. Ind. Coop. Soc. 2020, 2, 512-520.

19. Lee, W.H.; Kim, J.Y.; Hong, W.H.; Ahn, C.H. A study on recovery time of ground water temperature of small scale GWHP using standing column well in case of heating. J. Archit. Inst. Korea 2008, 24, 223-230.

20. Yang, S.J.; Kim, J.Y.; Hong, W.H.; Ahn, C.H. An analysis of underground water temperature during heating and cooling by small-scale scw type GWHP system in operation modes. J. Archit. Inst. Korea 2009, 25, 263-270.

21. Lee, D.Y.; Seo, B.M.; Choi, J.M.; Lee, K.H. Comparative analysis of the heating energy performance of SCW geothermal heat pump system with and without heat storage tank. Soc. Air-Cond. Refrig. Eng. Korea 2018, 6, 77-80.

22. Lee, S.H.; Park, J.S.; Byun, S.J.; Park, C.H.; Lee, C.H. An experimental study on improvement of ground thermal conductivity by reinjection method of bleed drainage of SCW type heat exchanger. Korean Soc. New Renew. Energy 2018, 11, 226.

23. You, J.; Lee, C. Comparative analysis of geothermal energy in Korea based on closed borehole and singleand two-well standing column well geothermal heat exchange systems. Appl. Sci. 2020, 10, 2467. [CrossRef]

24. Lee, C. Thermal performance of a standing column well geothermal heat exchanger system using re-injection of bleeding water. Geothermics 2019, 82, 73-80. [CrossRef]

25. García-Gil, A.; Abesser, C.; Cavero, S.G.; Marazuela, M.Á.; Lázaro, J.M.; Vázquez-Suñé, E.; Hughes, A.G.; Moreno, M.M. Defining the exploitation patterns of groundwater heat pump systems. Sci. Total. Environ. 2020, 710, 136425. [CrossRef]

26. García-Gil, A.; Maya, S.M.; Garrido, E.; Moreno, M.M.; Vázquez-Suñé, E.; Marazuela, M.; Lázaro, J.M.; Sánchez-Navarro, J.Á. Sustainability indicator for the prevention of potential thermal interferences between groundwater heat pump systems in urban aquifers. Renew. Energy 2019, 134, 14-24. [CrossRef]

27. García-Gil, A.; Mejías Moreno, M.; Garrido Schneider, E.; Marazuela, M.Á.; Abesser, C.; Mateo Lázaro, J.; Sánchez Navarro, J.Á. Nested shallow geothermal systems. Sustainability 2020, 12, 5152. [CrossRef] 
28. Meng, B.; Vienken, T.; Kolditz, O.; Shao, H. Modeling the groundwater temperature response to extensive operation of ground source heat pump systems: A case study in Germany. Energy Procedia 2018, 152, 971-977. [CrossRef]

29. Maya, S.M.; García-Gil, A.; Garrido, E.; Moreno, M.M.; Epting, J.; Vázquez-Suñé, E.; Marazuela, M.Á.; Sánchez-Navarro, J.Á. An upscaling procedure for the optimal implementation of open-loop geothermal energy systems into hydrogeological models. J. Hydrol. 2018, 563, 155-166. [CrossRef]

30. Li, W.; Li, X.; Peng, Y.; Wang, Y.; Tu, J. Experimental and numerical studies on the thermal performance of ground heat exchangers in a layered subsurface with groundwater. Renew. Energy 2020, 147, 620-629. [CrossRef]

31. Lee, C.; You, J.; Park, H. In-situ response test of various borehole depths and heat injection rates at standing column well geothermal heat exchanger systems. Energy Build. 2018, 172, 201-208. [CrossRef]

32. Eskilson, P. Thermal Analysis of Heat Extraction Boreholes. Ph.D. Thesis, Department of Mathematical Physics, University of Lund, Lund, Sweden, 1987.

33. Lamarche, L.; Beauchamp, B. A new contribution to the finite line-source model for geothermal boreholes. Energy Build. 2007, 39, 188-198. [CrossRef]

34. Luo, Y.; Yu, J.; Yan, T.; Zhang, L.; Liu, X. Improved analytical modeling and system performance evaluation of deep coaxial borehole heat exchanger with segmented finite cylinder-source method. Energy Build. 2020, 212, 109829. [CrossRef]

35. Choi, H.-K.; Yoo, G.-J.; Lim, K.-B.; Lee, S.-H.; Lee, C.-H. Thermal performance analysis of borehole size effect on geothermal heat exchanger. J. Central South. Univ. 2012, 19, 3524-3529. [CrossRef]

36. Minea, V. Experimental investigation of the reliability of residential standing column heat pump systems without bleed in cold climates. Appl. Therm. Eng. 2013, 52, 230-243. [CrossRef]

37. Jia, G.; Tao, Z.; Meng, X.; Ma, C.; Chai, J.; Jin, L. Review of effective thermal conductivity models of rock-soil for geothermal energy applications. Geothermics 2019, 77, 1-11. [CrossRef]

38. Gehlin, S.E.; Hellstrom, G. Comparison of four models for thermal response test evaluation. ASHRAE Trans. 2003, 109, 131-142.

39. Morgensen, P. Fluid to duct wall heat transfer in duct system heat storage. In Proceedings of the International Conference on Subsurface Heat Storage in Theory and Practice, Stockholm, Sweden, 6-8 June 1983; pp. 625-657.

40. Yu, X.; Zhang, Y.; Deng, N.; Ma, H.; Dong, S. Thermal response test for ground source heat pump based on constant temperature and heat-flux methods. Appl. Therm. Eng. 2016, 93, 678-682. [CrossRef]

41. Yu, X.; Zhang, Y.; Deng, N.; Wang, J.; Zhang, D.; Wang, J. Thermal response test and numerical analysis based on two models for ground-source heat pump system. Energy Build. 2013, 66, 657-666. [CrossRef]

42. Marcotte, D.; Pasquier, P. On the estimation of thermal resistance in borehole thermal conductivity test. Renew. Energy 2008, 33, 2407-2415. [CrossRef]

43. Borinaga-Treviño, R.; Pascual-Muñoz, P.; Castro-Fresno, D.; Blanco-Fernandez, E. Borehole thermal response and thermal resistance of four different grouting materials measured with a TRT. Appl. Therm. Eng. 2013, 53, 13-20. [CrossRef]

Publisher's Note: MDPI stays neutral with regard to jurisdictional claims in published maps and institutional affiliations.

(C) 2020 by the authors. Licensee MDPI, Basel, Switzerland. This article is an open access article distributed under the terms and conditions of the Creative Commons Attribution (CC BY) license (http://creativecommons.org/licenses/by/4.0/). 